DOE/NV/-500

UC-700

Nevada

Environmental

Restoration

Project

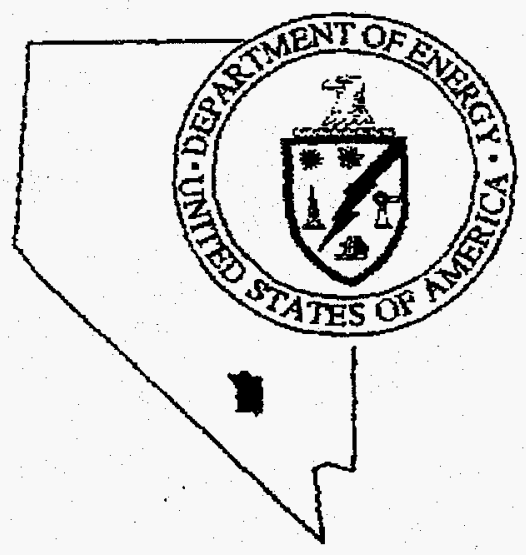

Recompletion

Report for

BILBY

February 1998

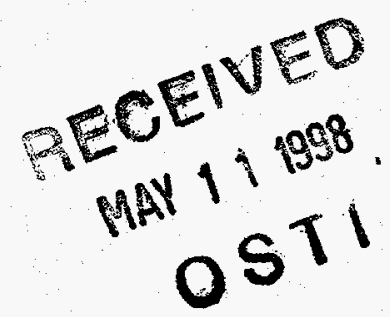

Environmental Restoration

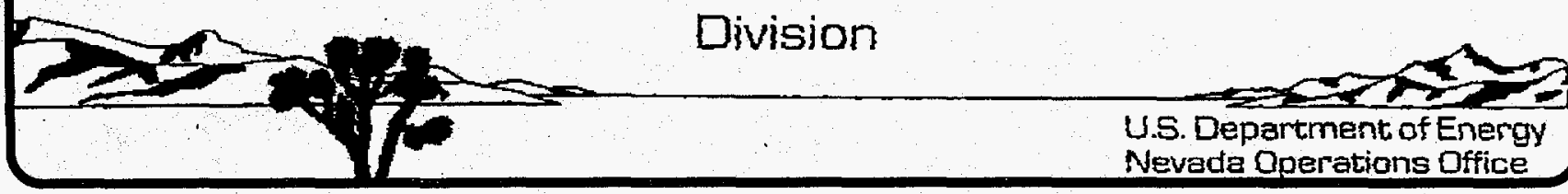


This report has been reproduced from the best available copy.

Available to DOE and DOE contractors from the Office of Scientific and Technical Information, P.O. Box 62, Oak Ridge, TN 37831; prices available from (423) 576-8401.

Available to the public from the National Technical Information Service, U.S. Department of Commerce, 5285 Port Royal Rd., Springfield, VA 22161; telephone (703) 487-4650. 
DOE/NV--500

UC-700

\section{RECOMPLETION REPORT FOR BILBY}

Prepared for:

DOE Nevada Operations Office

Las Vegas, Nevada

February 1998

MASTER

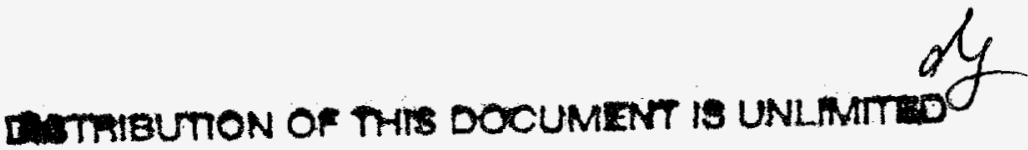


This Page Intentionally Left Blank. 


\section{DISCLAIMER}

Portions of this document may be illegible electronic image products. Images are produced from the best available original document. 


\section{Recompletion Report for BILBY}

Approved by: Robent Mr. Bangesten In.

Robert M. Bangerter, Project Manager,

Underground Test Area Subproject

Approved by:
Date: $2 / 26 / 48$

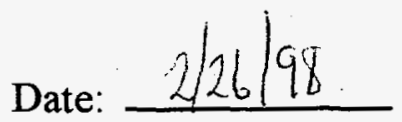

fo Michael O. Giblin, Acting Project Manager,

Nevada Environmental Restoration Project 
This Page Intentionally Left Blank. 


\section{Table of Contents}

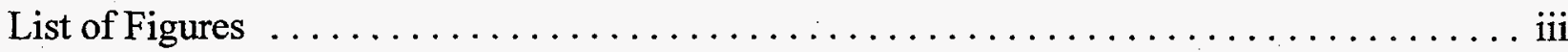

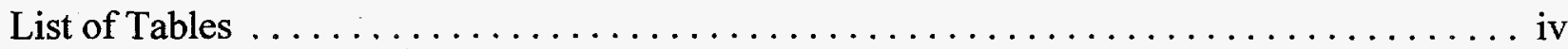

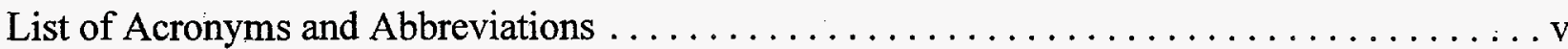

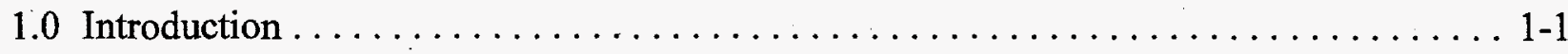

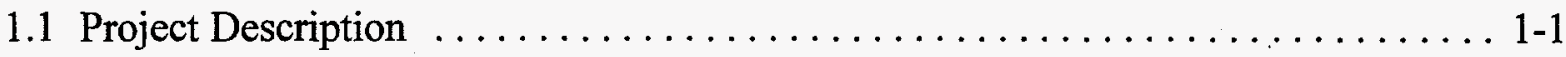

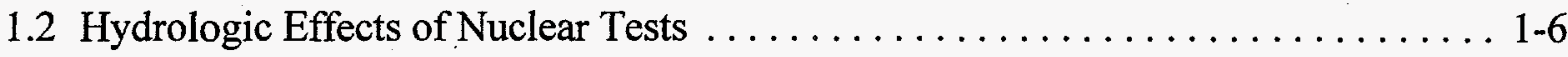

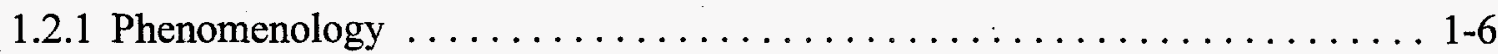

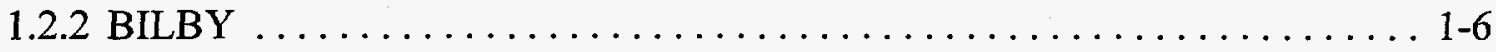

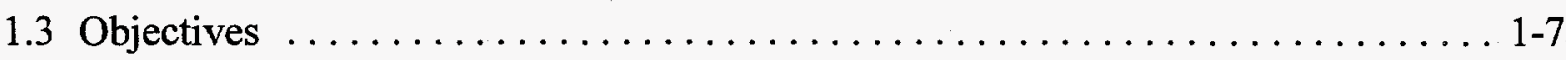

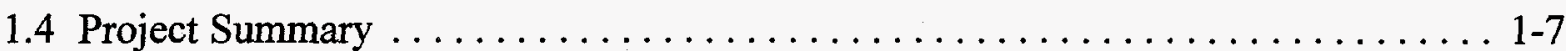

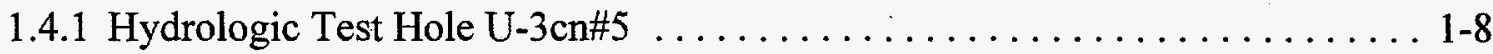

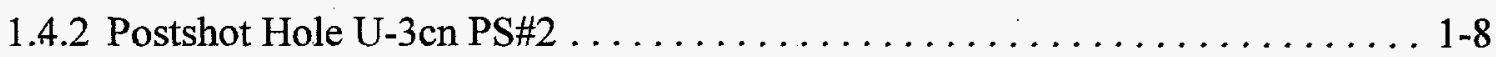

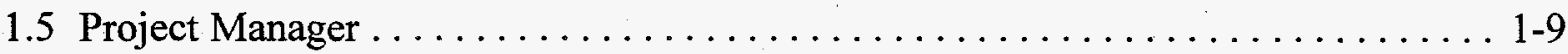

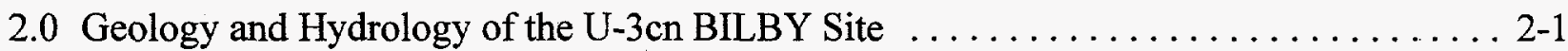

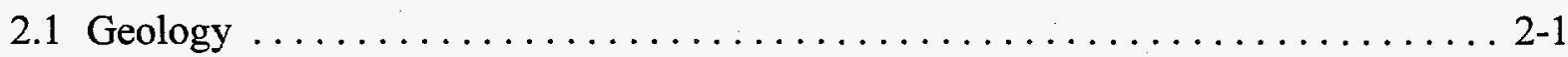

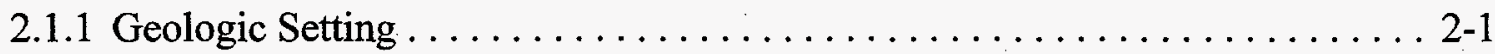

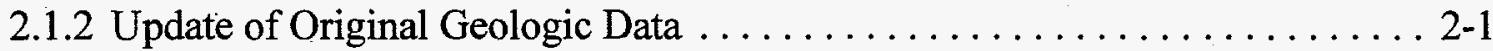

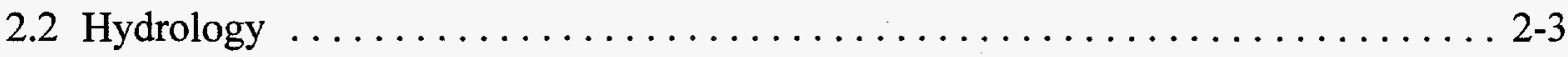

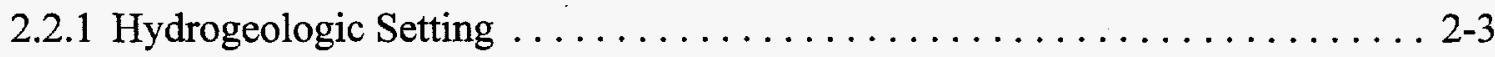

2.2.2 Results of Previous Hydrologic Investigations $\ldots \ldots \ldots \ldots \ldots \ldots \ldots .2-6$

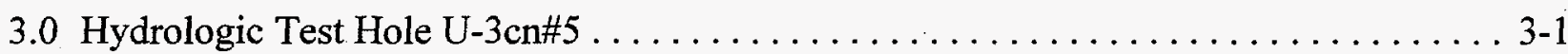

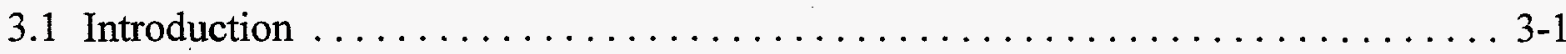

3.2 Activities Summary for Hydrologic Test Hole U-3cn\#5 . . . . . . . . . . . . . 3-1

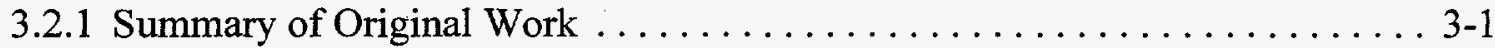

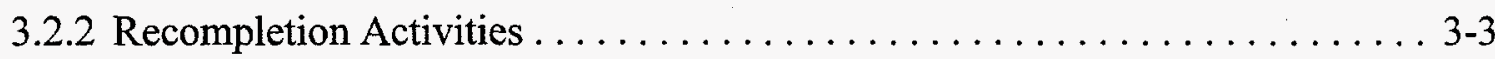

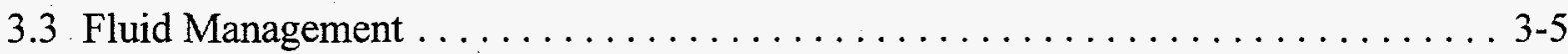

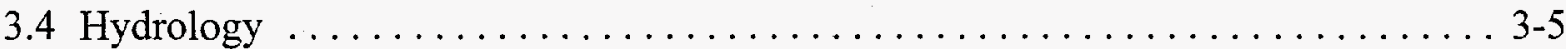

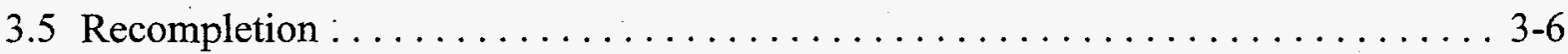

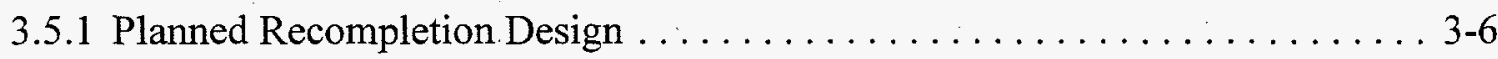

3.5.2 As-Built Recompletion Design $\ldots \ldots \ldots \ldots \ldots \ldots \ldots \ldots \ldots \ldots \ldots . \ldots \ldots$ 


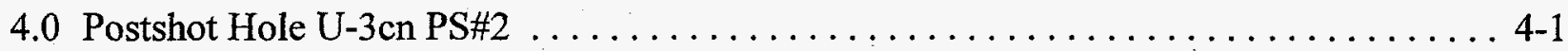

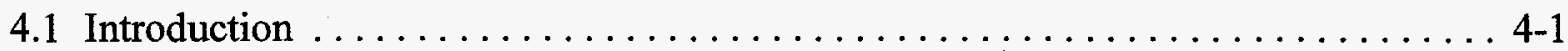

4.2 Activities Summary for Postshot Hole U-3cn PS\#2 . . . . . . . . . . . . . . 4-1

4.2.1 Summary of Original Work $\ldots \ldots \ldots \ldots \ldots \ldots \ldots \ldots \ldots \ldots \ldots, 4-1$

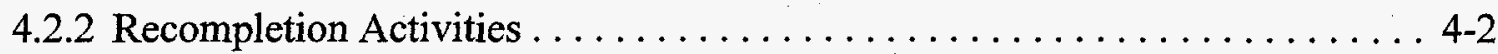

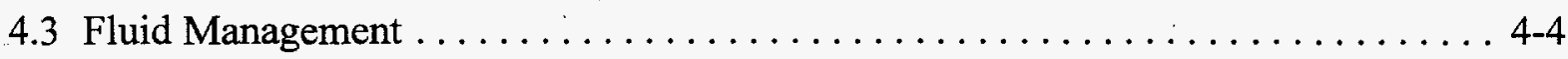

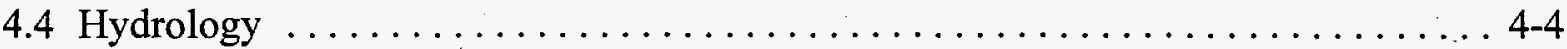

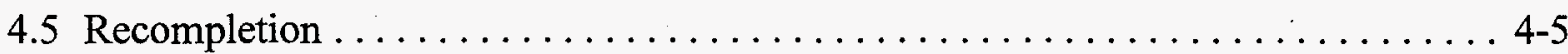

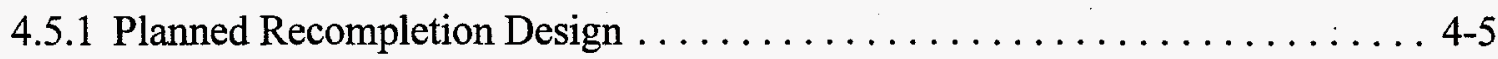

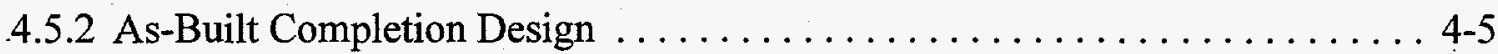

5.0 Summary, Recommendation, and Lessons Learned from the

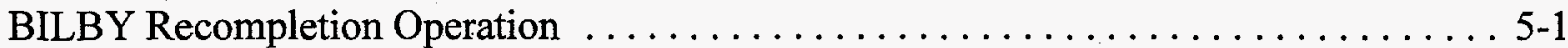

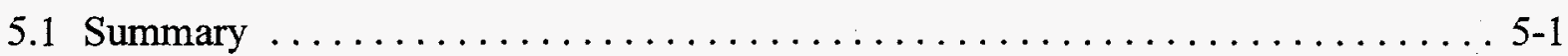

5.2 Recommendations for Additional Data Interpretation $\ldots \ldots \ldots \ldots \ldots \ldots \ldots .2$

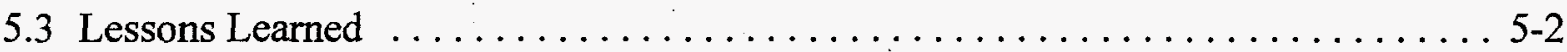

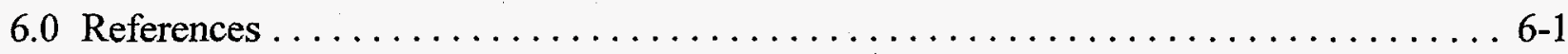

Appendix A - Completion and Recompletion Data .................... A-1

A-1 Recompletion Histories for Hydrologic Test Hole U-3cn\#5 and Postshot Hole U-3cn PS\#2

A-2 Casing and Tubing Data for Hydrologic Test Hole U-3cn\#5 and Postshot Hole U-3en PS\#2

Appendix B - Stratigraphic and Lithologic Logs for Hydrologic Test Hole U-3cn\#5 . . . . . B-1 


\section{List of Figures}

Number

Title

Page

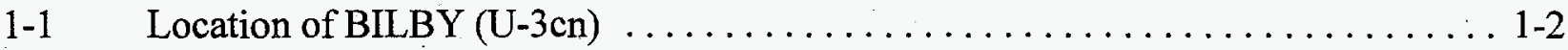

1-2 Area Map for U-3en BILBY Recompletion Project $\ldots \ldots \ldots \ldots \ldots \ldots \ldots \ldots$

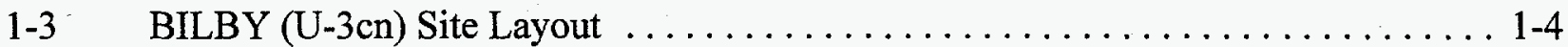

2-1 West-East Hydrogeologic Cross Section Through the BILBY Area $\ldots \ldots \ldots \ldots .2-2$

3-1 Graph of Directional Survey in Hydrologic Test Hole U-3cn\#5 . . . . . . . . . 3-2

3-2 Recompletion Diagram for Hydrologic Test Hole $U-3 c n \# 5 \ldots \ldots \ldots \ldots \ldots .7$

3-3 Wellhead Diagram for Hydrologic Test Hole U-3cn\#5 $\ldots \ldots \ldots \ldots \ldots \ldots \ldots$ 3-8

4-1 Graph of Directional Survey in Postshot Hole U-3cn PS\#2 $\ldots \ldots \ldots \ldots \ldots \ldots .4-2$

4-2 Completion Diagram for Postshot Hole U-3en PS\#2 $\ldots \ldots \ldots \ldots \ldots \ldots \ldots$ 4-6

4-3 Wellhead Diagram for Postshot Hole U-3en PS\#2 $\ldots \ldots \ldots \ldots \ldots \ldots \ldots \ldots .4$

5-1 Southwest-Northeast Diagrammatic Cross Section Through BILBY and Hydrologic Test Hole U-3cn\#5 


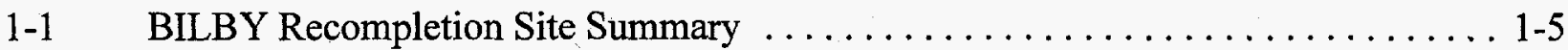

1-2 Synopsis of Pertinent Data for the BILBY Underground Nuclear Test $\ldots \ldots \ldots \ldots$ 1-7

2-1 Stratigraphic, Lithologic, and Hydrogeologic Units at the U-3en BILBY Site . . . . 2-4

2-2 Depth to Selected Formation Tops and General Drill Hole Information for Drill Holes U-3en, U-3en\#5, and U-3en PS\#2 $\ldots \ldots \ldots \ldots \ldots \ldots \ldots .2-5$

2-3 Summary of Hydraulic Tests at Hydrologic Test Hole U-3cn\#5 $\ldots \ldots \ldots \ldots \ldots .2-7$

3-1 Abridged Drill Hole Statistics for Hydrologic Test Hole U-3cn\#5 . . . . . . . . . . . 3-4

3-2 Hydrologic Test Hole U-3cn\#5 Construction Summary . . . . . . . . . . . . 3-9

4-1 Abridged Drill Hole Statistics for Postshot Hole U-3cn PS\#2 . . . . . . . . . . . . 4-3

4-2 Dissolved Radionuclides in Groundwater Samples from

Postshot Hole U-3cn PS\#2 (through 1965) . ................... 4-5

4-3 Postshot Hole U-3cn PS\#2 Construction Summary $\ldots \ldots \ldots \ldots \ldots \ldots \ldots .4 .8$ 


\section{List of Acronyms and Abbreviations}

BN Bechtel Nevada

cm Centimeters

DOB Depth of burial

DOE/NV U.S. Department of Energy, Nevada Operations Office

$\mathrm{ft} \quad$ Foot (feet)

gal Gallon(s)

HGU Hydrogeologic Unit

HP Horsepower

hrs Hours

id Inside diameter

in. Inch(es)

IT IT Corporation

m Meter(s)

$\mathrm{m}^{3} \quad$ Cubic meters

NTS Nevada Test Site

od Outside diameter

$\mathrm{pCi} / \mathrm{L} \quad$ PicoCurie(s) per liter

TD Total depth

UGTA Underground Test Area

USGS U.S. Geological Survey

WP Working Point 
This Page Intentionally Left Blank. 


\subsection{Introduction}

\subsection{Project Description}

The BILBY recompletion project was conducted in December 1996 and January 1997 for the U.S. Department of Energy, Nevada Operations Office (DOE/NV) in support of the Nevada Environmental Restoration Project at the Nevada Test Site (NTS), Nye County, Nevada. This project is part of the DOE's Underground Test Area (UGTA) subproject at the NTS. The primary UGTA tasks include collecting geological, geophysical, and hydrological data from new and existing wells to define groundwater quality and to determine pathways and rates of groundwater migration at the NTS. A program of drilling or recompleting wells near the sites of selected underground nuclear tests (near-field studies) was implemented as part of the UGTA subproject to obtain site-specific data on the nature and extent of migration of radionuclides produced by an underground nuclear detonation.

The BILBY project is named for the underground nuclear test conducted in Emplacement Hole $\mathrm{U}-3 \mathrm{cn}$ in 1963. The BILBY site is located in Area 3 of the NTS, in the central portion of Yucca Flat (Figures 1-1 and 1-2). The site consists of a collapse sink (centered on the collar of the original emplacement hole) and several wells collared within the sink (Figure 1-3). Two of the wells were recompleted for this project. Postshot Hole U-3cn PS\#2 was drilled through the chimney rubble into the explosion cavity to a depth of 793.4 meters $(\mathrm{m})(2,603 \mathrm{feet}[\mathrm{ft}])$ soon after the detonation in 1963. Hydrologic Test Hole U-3cn\#5 was drilled outside but near the chimney two years after the nuclear test to a total depth (TD) of $923.5 \mathrm{~m}(3,030 \mathrm{ft})$.

Data from the original studies in these two wells are not adequate for use in making projections of the present condition of the groundwater system around the BILBY site because of various uncertainties related to the test conditions (low pumped volumes, low gradient) and because of unanswered questions about how radionuclides migrated within fracture systems. Although no rapid or extensive migration of radionuclides was found in the original studies, scientists can not determine the current status with the existing data set (Buddemeier and Isherwood, 1985). However, a large volume of geologic and baseline hydrologic data is available for the BILBY site. Thus, the UGTA Technical Working Group, a committee of experts on NTS geology and the weapons testing program (consisting of DOE, Lawrence Livermore National Laboratory, Los Alamos National Laboratory, and contractor personnel), selected the BILBY site as a near-field study project because important questions about radionuclide migration might be answered 


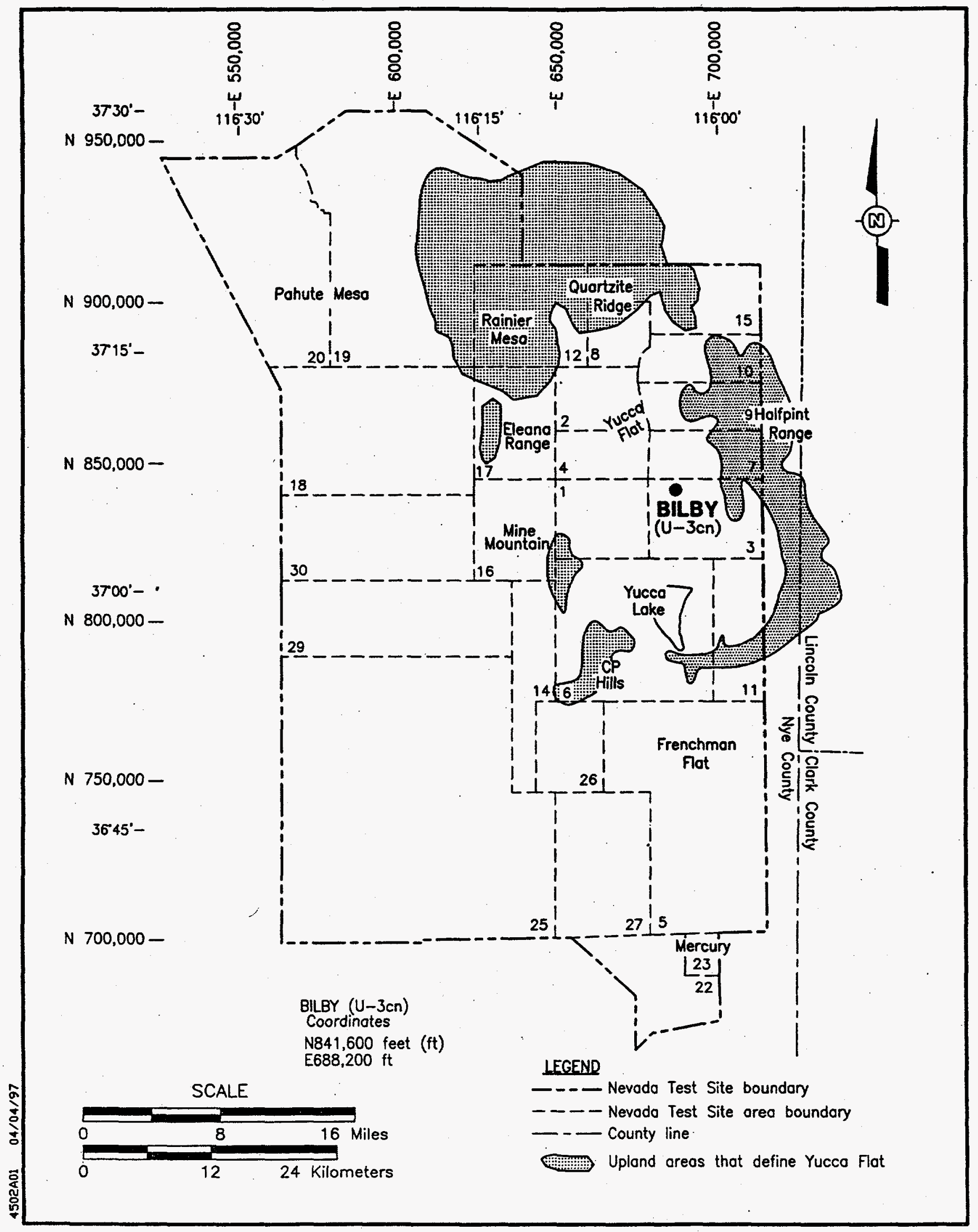

Figure 1-1

Location of BILBY (U-3cn) 


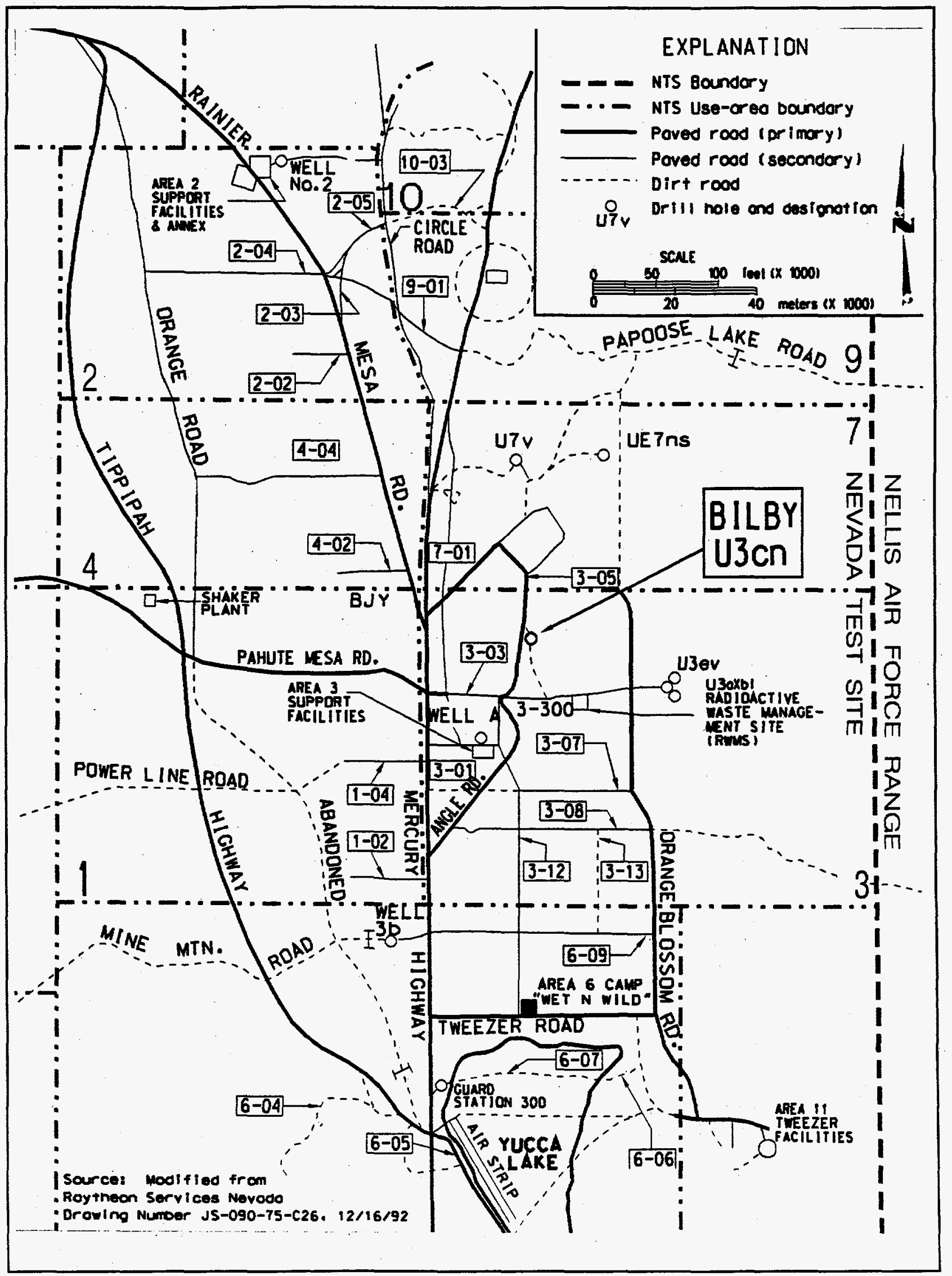

Figure 1-2

Area Map for U-3en BILBY Recompletion Project 


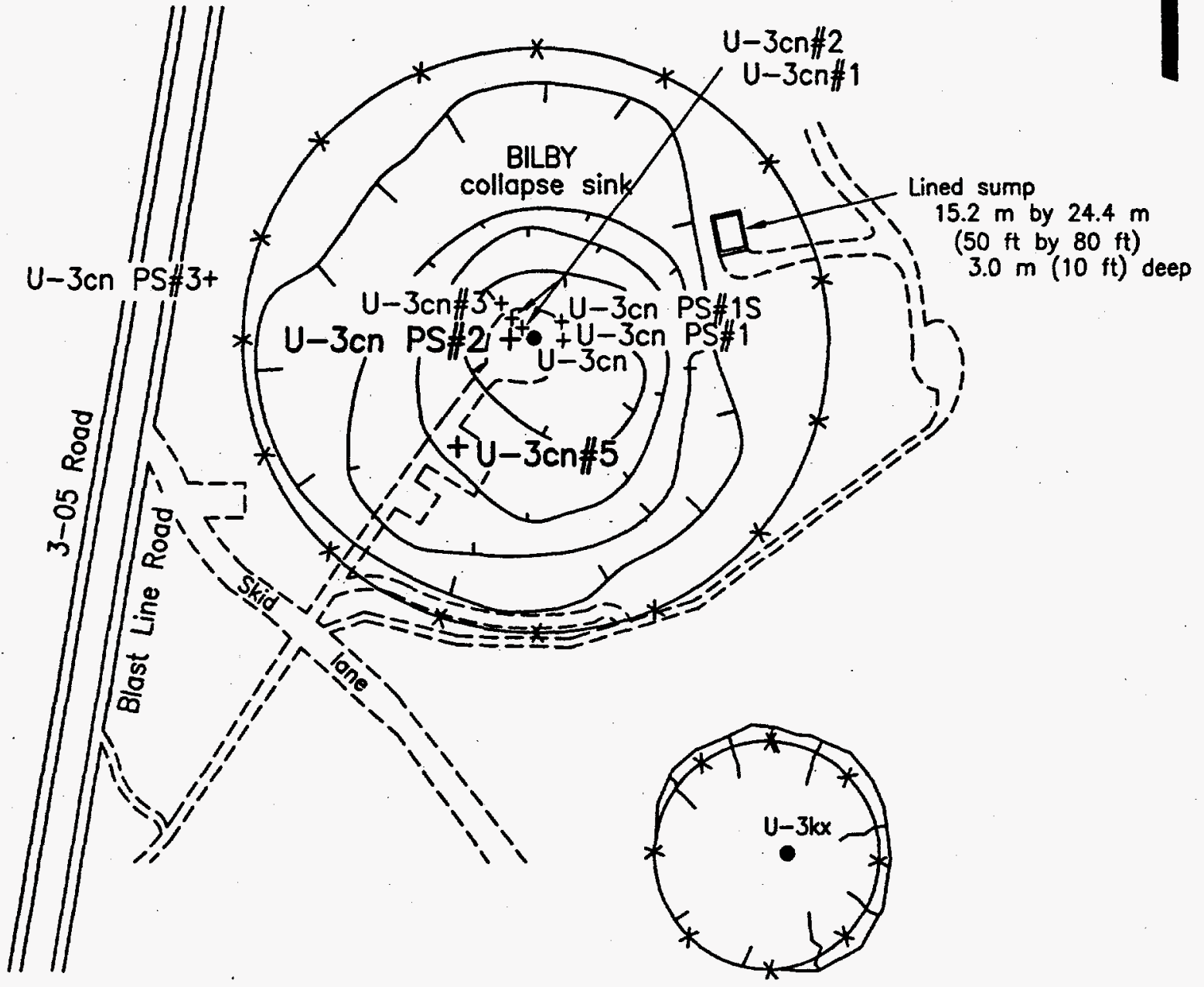

LEGEND

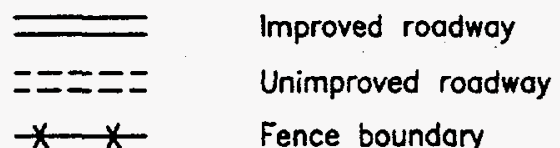

SCALE

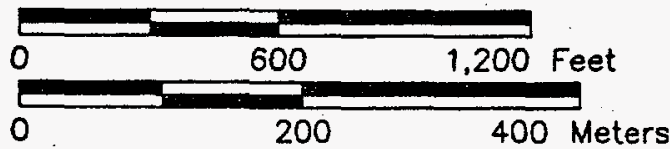

$\Gamma T \lambda \quad \begin{aligned} & \text { Contour line within the } \\ & \text { surfoce collopse sink }\end{aligned}$

(6-m [20-ft] interval)

- U-3en Emplacement hole

+ U-3en PS\$2 Drill hole

\section{Figure 1-3}

BILBY (U-3cn) Site Layout 
simply by replacing well hardware, conducting hydrologic tests, and monitoring groundwater quality.

The initial phase of this project (through January 1997, reported here) consisted of the evaluation, rehabilitation, and sampling of Hydrologic Test Hole U-3cn\#5 and Postshot Hole U-3cn PS\#2. The Nevada State Planar Coordinates and elevation of both well collars are provided in Table 1-1, along with additional site summary and survey information.

Table 1-1

BILBY Recompletion Site Summary

\begin{tabular}{|c|c|c|c|}
\hline \multicolumn{2}{|c|}{ Hole Designation } & $\begin{array}{l}\text { Hydrologic Test } \\
\text { Hole U-3cn\# }\end{array}$ & $\begin{array}{l}\text { Postshot Hole } \\
\text { U-3cn PS\#2 }\end{array}$ \\
\hline \multirow{2}{*}{ Site Coordinates $^{a}$} & Central Nevada State Planar (ft) & $\begin{array}{l}N 841,255 \\
\text { E687,998 }\end{array}$ & $\begin{array}{l}N 841,600 \\
E 688,169\end{array}$ \\
\hline & $\begin{array}{l}\text { Universal Transverse Mercator } \\
\text { (Zone 11) }(\mathrm{m})\end{array}$ & $\begin{array}{l}\mathrm{N} 4,101,713.7 \\
\mathrm{E} 586,921.8\end{array}$ & $\begin{array}{l}\mathrm{N} 4,101,819.0 \\
\mathrm{E} 586,973.6\end{array}$ \\
\hline \multicolumn{2}{|c|}{ Surface Elevation $^{\mathrm{b}}$} & $\begin{array}{l}1,222.9 \mathrm{~m} \\
(4,012 \mathrm{ft})\end{array}$ & $\begin{array}{l}1,217.4 \mathrm{~m} \\
(3,994 \mathrm{ft})\end{array}$ \\
\hline \multicolumn{2}{|c|}{ Drilled Depth } & $\begin{array}{l}923.5 \mathrm{~m} \\
(3,030 \mathrm{ft})\end{array}$ & $\begin{array}{l}793.4 \mathrm{~m} \\
(2,603 \mathrm{ft})\end{array}$ \\
\hline \multicolumn{2}{|c|}{ Fluid-Level Depth } & $\begin{array}{l}493.9 \mathrm{~m}^{\mathrm{c}} \\
(1,620 \mathrm{ft})\end{array}$ & $\begin{array}{l}472.4 \mathrm{~m}^{\mathrm{d}} \\
(1,550 \mathrm{ft})\end{array}$ \\
\hline \multicolumn{2}{|c|}{ Fluid-Level Elevation } & $\begin{array}{l}729.1 \mathrm{~m} \\
(2,392 \mathrm{ft})\end{array}$ & $\begin{array}{r}744.9 \mathrm{~m} \\
(2,444 \mathrm{ft})\end{array}$ \\
\hline
\end{tabular}

Sources: RSN (1991); BN (1996).

a. 1927 North American Datum. Measurement made by Holmes \& Narver Survey.

b 1929 North American Vertical Datum. Measurement by Homes \& Narver Survey.

c Measurement by USGS, December 1996 (Trudeau, 1997).

d Fluid level from logs by Birdwell in 1977 (Arteaga et al. [1991]).

IT Corporation (IT) was the principal environmental contractor for the project. Engineering, well-site support, inspection, and geotechnical services were provided by Bechtel Nevada (BN). The work planned to accomplish the recompletions is described in BN Drilling Program Number D-012-001.96 (BN, 1996). Descriptions of the BILBY site, summaries of previous studies, and preconstruction conditions are provided in the Bilby Recompletion Criteria Technical Letter (IT, 1995). The UGTA fluid-management plan (DOE, 1994a) provided guidelines for handling potentially radioactive fluids produced during pumping and sampling of these holes. 
This document presents well-design and recompletion data for the two BILBY wells that were pumped and sampled for this project. Some summary data on geology, hydrology, and previous activities at the site are also included here for the convenience of the reader. The results of pumping and sampling activities will be presented in a separate report.

\subsection{Hydrologic Effects of Nuclear Tests}

\subsubsection{Phenomenology}

Underground nuclear explosions cause physical changes in the near field as a result of ground shock, cavity growth, and chimney formation. Temporary increases in temperature and fluid pressure, and in some cases the groundwater level, have been observed. More permanent changes expected in the near field include enhanced fracture permeability, increased porosity due to bulking of broken material in the cavity/chimney area, and the creation of a potentially permeable vertical conduit between aquifers through the chimney material (Garber, 1971a; Brikowski, 1991).

\subsubsection{BILBY}

The BILBY underground nuclear test, executed in Emplacement Hole U-3cn on September 13, 1963, was the first nuclear explosion conducted below the water table at the NTS. See Table 1-2 for a summary of data for the BILBY nuclear test. Observations made following previous underground explosions indicated that groundwater levels near test locations could be affected, at least temporarily, so the BILBY test plan included "real-time" monitoring of groundwater levels to determine if the explosion caused any such changes. Also, because of BILBY's relatively large yield (249 kilotons [DOE, 1994b]) and because the explosion cavity was located close to the lower carbonate aquifer, scientists thought that radionuclides released by the explosion could possibly have been introduced into this regional aquifer. Thus, several studies were conducted in the years following the test to try to develop an understanding of the close-in effects of nuclear tests on the groundwater system and the distribution of explosion-produced radioactivity in the environment. Data from the postshot hole provided valuable information on the recovery of the water table after the explosion and on the hydrologic characteristics of the chimney rubble (Garber, 1971b; Buddemeier and Isherwood, 1985). Data from the hydrologic test hole indicated that as of 1981 no radionuclides had been detected in the regional aquifer in that area.

Detailed reports on the drilling and testing of these two holes can be found in Hale et al. (1963), Garber and Johnston (1967), and Garber (1971b). An evaluation of the results from all the data available from this site through 1984 can be found in Buddemeier and Isherwood (1985). 
Table 1-2

Synopsis of Pertinent Data for the BILBY Underground Nuclear Test

\begin{tabular}{|c|c|}
\hline Emplacement Hole Designation & $U-3 c n$ \\
\hline Central Nevada State Planar Coordinates & $\begin{array}{l}N 841,600 \mathrm{ft} \\
\text { E688,200 ft }\end{array}$ \\
\hline Surface Elevation & $1,241.8 \mathrm{~m}(4,074 \mathrm{ft})$ \\
\hline Drilled Depth & $785.5 \mathrm{~m}(2,577 \mathrm{ft})$ \\
\hline Water-Table Depth & $502.9 \mathrm{~m}(1,650 \mathrm{ft})$ \\
\hline Water-Table Elevation & $738.8 \mathrm{~m}(2,424 \mathrm{ft})$ \\
\hline Test Date & September 13,1963 \\
\hline Announced Yield & 249 kilotons \\
\hline Depth of Burial (DOB) & $713.2 \mathrm{~m}(2,340 \mathrm{ft})$ \\
\hline Geologic Medium at DOB & Zeolitized, nonwelded ash-flow tuff \\
\hline Estimated Cavity Radius & $87 \mathrm{~m}(285 \mathrm{ft})$ \\
\hline $\begin{array}{l}\text { Surface Collapse Sink } \\
\text { Depth } \\
\text { North-south diameter } \\
\text { East-west diameter }\end{array}$ & $\begin{array}{l}24.7 \mathrm{~m}(81 \mathrm{ft}) \text { at maximum } \\
487.7 \mathrm{~m}(1,600 \mathrm{ft}) \\
457.2 \mathrm{~m}(1,500 \mathrm{ft})\end{array}$ \\
\hline
\end{tabular}

Sources: DOE (1994b) and Williams (1964).

\subsection{Objectives}

The primary objective of the BILBY recompletion project was to reestablish a means of investigating the impact of the BILBY underground nuclear test on the lower carbonate aquifer in southern Yucca Flat. The rehabilitation of the submersible pumps in Hydrologic Test Hole U-3cn\#5 and Postshot Hole U-3cn PS\#2 is expected to enable long-term monitoring of groundwater near the BILBY test.

\subsection{Project Summary}

This section briefly summarizes drilling and completion data for the BILBY site. A summary of the geology and hydrology, and the details of the recompletion activities are given in Sections 2 and 3 of this report.

Prior to work on the pumps in Wells U-3cn\#5 and U-3cn PS\#2 a new, lined sump and fences were constructed at the BILBY site, and an exclusion zone was established. Appropriate barriers 
such as plastic linings were installed at the wellheads to prevent soil contamination by lubricants and other fluids from the equipment.

\subsubsection{Hydrologic Test Hole U-3cn\#5}

Hydrologic Test Hole U-3cn\#5, located approximately $40 \mathrm{~m}(130 \mathrm{ft})$ outside the BILBY collapse

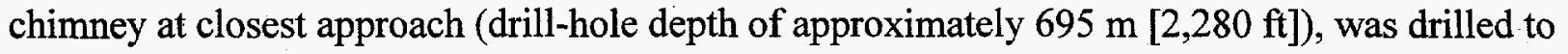
the depth of $923.5 \mathrm{~m}(3,030 \mathrm{ft})$ in 1966, and completed with a submersible pump and an access line. The hole was cased to a depth of $863 \mathrm{~m}(2,832 \mathrm{ft})$, leaving the lower $60.4 \mathrm{~m}(198 \mathrm{ft})$ of the hole open to Paleozoic-age carbonate rocks of the lower carbonate aquifer. The well was used for hydrologic testing and sampling through 1981 when the pump failed, but the U.S. Geological Survey (USGS) continues to measure water levels intermittently.

A Franks 300 drill rig was used to pull the existing pump string for evaluation on January 15-16, 1997. Forty-two joints of the existing $2 \%$-inch (in.) pump string were replaced due to excessive rust. A 50-horsepower (HP) Centrilift ${ }^{\mathrm{TM}}$ tandem pump was lowered on the refurbished pump string, and set with its bottom at $691.3 \mathrm{~m}(2,268.1 \mathrm{ft})$ on January 23,1997 . The pump intake is located at $687.6 \mathrm{~m}(2,255.8 \mathrm{ft})$. The existing $23 / 8$-in. access tube was left in place with its bottom set at $701.0 \mathrm{~m}(2,300 \mathrm{ft})$. After the new pump was installed, a 46-hour pumping test was conducted and water samples were taken for analysis. Pumping and sampling of Hydrologic Test Hole U-3cn\#5 were concluded on January 30, 1997.

\subsubsection{Postshot Hole U-3en PS\#2}

Postshot Hole U-3cn PS\#2 was drilled through the rubble of the BILBY collapse chimney and into the explosion cavity in 1963 . The total depth of the original hole was $793.4 \mathrm{~m}(2,603 \mathrm{ft})$, and the hole was cased to $792.2 \mathrm{~m}(2,599 \mathrm{ft})$. This 41/2-in. casing was perforated in the interval 579.1 to $792.2 \mathrm{~m}(1,900-2,599 \mathrm{ft})$, but the casing soon pinched off or collapsed at approximately $587 \mathrm{~m}(1,926 \mathrm{ft})$. A packer was set at $561.4 \mathrm{~m}(1,842 \mathrm{ft})$, and additional perforations were made at 512.1 to $527.0 \mathrm{~m}(1,680-1,729 \mathrm{ft})$; now only the rubble-chimney environment can be sampled in this configuration. The original submersible pump was located at a depth of $520.9 \mathrm{~m}$ $(1,709 \mathrm{ft})$, but failed and was replaced. An 8.9-centimeter (cm) $\left(3 \frac{1}{2}\right.$-in.) 10-HP Reda TM submersible pump was installed in September 1977 on 12/3-in. Hydril ${ }^{\text {TM }}$ tubing, with the intake at 503.5 to $504.7 \mathrm{~m}(1,652-1,656 \mathrm{ft})$. The well was sampled intermittently through 1984 .

The existing pump was tested on January 9, 1997 and found to be operable. A 140-hour pumping test was conducted and water samples were taken for analysis. Pumping and sampling of Postshot Hole U-3cn PS\#2 were concluded on January 22, 1997. 


\subsection{Project Manager}

Inquiries regarding the BILBY recompletion project should be directed to the UGTA Project Manager:

Environmental Restoration Division

DOE/Nevada Operations Office

Post Office Box 98518

Las Vegas, Nevada 89193-8518 
This Page Intentionally Left Blank. 


\subsection{Geology and Hydrology of the U-3cn BILBY Site}

\subsection{Geology}

The geology of the BILBY site in central Yucca Flat is well known from extensive geologic studies associated with underground nuclear testing in the area, and from analyses of data obtained during the drilling and sampling of the original BILBY holes themselves (Emplacement Hole U-3cn, Well U-3cn\#4, Hydrologic Test Hole U-3cn\#5, Postshot Hole U-3cn PS\#2). Data from the BILBY holes are presented in various USGS reports and summarized in the Bilby Recompletion Criteria Technical Letter (IT, 1995). Features that are relevant to the UGTA nearfield program are described in the following paragraphs. No new geologic data were collected during the BILBY recompletion activities.

\subsubsection{Geologic Setting}

Yucca Flat is an arid, intermontane valley typical of the Basin and Range province of Nevada. The valley was formed by faulting of the Paleozoic-age sedimentary rocks, and has been filled with tuffs and alluvium. The alluvium consists of tuffaceous sands and gravels at the BILBY site, and ranges in thickness from about 260 to $290 \mathrm{~m}(850-950 \mathrm{ft})$. The alluvium is underlain by a series of Tertiary-age ash-flow tuffs and bedded tuffs approximately $536 \mathrm{~m}(1,760 \mathrm{ft})$ thick, which are separated from the underlying Paleozoic-age carbonate rocks by a colluvial layer approximately $41 \mathrm{~m}(135 \mathrm{ft})$ thick at BILBY. The upper $108 \mathrm{~m}(355 \mathrm{ft})$ of the volcanic section is vitric, but the volcanic rocks become zeolitized below about $282 \mathrm{~m}(925 \mathrm{ft})$ below the surface. The Paleozoic rocks immediately beneath the BILBY site are mainly dolomites and dolomitic quartzites of the lower carbonate aquifer.

A west-east hydrogeologic cross section, constructed at approximately right angles to the local structural fabric through the BILBY site, is presented in Figure 2-1. As can be seen, no major faults are projected to pass closer than about $457 \mathrm{~m}(1,500 \mathrm{ft})$ from the edge of the BILBY explosion cavity.

\subsubsection{Update of Original Geologic Data}

The USGS conducted the original geologic studies at the BILBY site, as described in Williams and Hoover (1963); Garber and Johnston (1967); Garber (1971b); and Dixon et al. (1973). However, recent work on the stratigraphy of the Tertiary volcanic rocks of the NTS area has required that the original logs be updated to incorporate the latest stratigtraphic nomenclature. A listing of stratigraphic units present at the BILBY site, with map symbols, lithology, and 


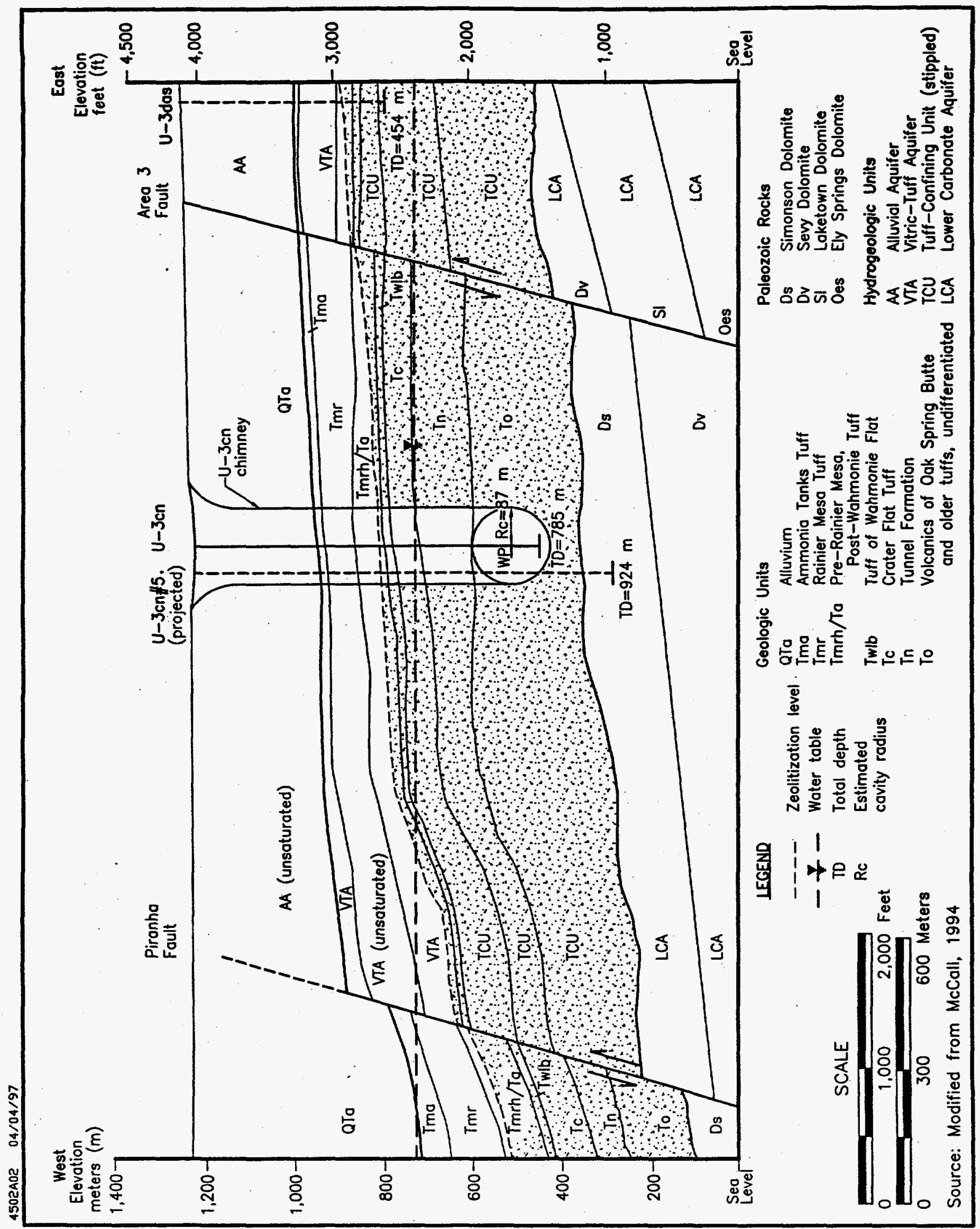

Figure 2-1

West-East Hydrogeologic Cross Section Through the BILBY Area 
hydrogeology, is given in Table 2-1. The updated stratigraphic and lithologic logs for Hydrologic Test Hole U-3cn\#5 are given in Appendix B. Because Postshot Hole U-3cn PS\#2 was drilled through the BILBY chimney rubble, no lithologic log is provided. Depths to selected formation tops and other drill hole information are presented for Emplacement Hole U-3cn, Hydrologic Test Hole U-3cn\#5, and Postshot Hole U-3cn PS\#2 in Table 2-2.

Lists of geophysical logs, conventional cores, and sidewall cores from Hydrologic Test Hole U-3cn\#5 can be found in Garber and Johnston (1967) and in the drill hole history (F\&S, 1966a). Descriptions of sidewall cores taken after drilling Postshot Hole U-3cn PS\#2 are given in Garber (1971b).

\subsection{Hydrology}

The hydrology of the BILBY site is summarized in the following paragraphs.

\subsubsection{Hydrogeologic Setting}

The rocks in the BILBY area can be divided into four hydrogeologic units (HGUs) that are distinguished by their differing abilities to transmit groundwater. These HGUs are defined on the basis of primary lithologic properties, degree of fracturing, and secondary mineral alteration. See Winograd and Thordarson (1975) and Laczniak et al. (1996) for more discussion of the hydrogeologic units in the NTS region.

Alluvial aquifer and vitric-tuff aquifer units are present above the static water table at BILBY, to

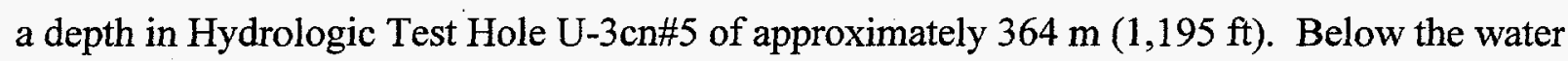
table the mostly zeolitized volcanic rocks and paleocolluvium are classified as a tuff confining unit. The BILBY detonation point (Working Point or WP) was located in a saturated, zeolitized, nonwelded ash-flow tuff of this tuff confining unit. The pre-Tertiary rocks, encountered at the depth of $860 \mathrm{~m}(2,821 \mathrm{ft}$ ) (approximately $166 \mathrm{~m}$ [545 ft] below the BILBY WP), are classified as lower carbonate aquifer. All of these HGUs are listed with the stratigraphic units on Table 2-1 and illustrated on Figure 2-1. 
Table 2-1

Stratigraphic, Lithologic, and Hydrogeologic Units at the U-3en BILBY Site

\begin{tabular}{|c|c|c|c|c|}
\hline $\begin{array}{l}\text { Stratigraphic } \\
\text { Group or } \\
\text { Formation } \\
\end{array}$ & Member or Unit & Symbol $^{a}$ & Typical Lithology & $\begin{array}{l}\text { Hydrogeologic } \\
\text { Unit }\end{array}$ \\
\hline Alluvium & Alluvium & Qta & Sands and gravels & Alluvial aquifer \\
\hline \multirow{4}{*}{$\begin{array}{c}\text { Timber Mountain } \\
\text { Group }\end{array}$} & $\begin{array}{l}\text { Ammonia Tanks } \\
\text { Tuff }\end{array}$ & Tma & Nonwelded ash-flow tuff & \multirow{3}{*}{ Vitric-tuff aquifer } \\
\hline & Rainier Mesa Tuff & Tmr & Nonwelded ash-flow tuff & \\
\hline & $\begin{array}{l}\text { Tuff of Holmes } \\
\text { Road }\end{array}$ & Tmrh & Vitric bedded tuff & \\
\hline & $\begin{array}{l}\text { Pre-Rainier Mesa, } \\
\text { Post-Wahmonie } \\
\text { tuffs, } \\
\text { undifferentiated }\end{array}$ & $\mathrm{Tmrh} / \mathrm{Ta}$ & Zeolitized bedded tuff & \multirow{8}{*}{ Tuff confining unit } \\
\hline $\begin{array}{l}\text { Wahmonie } \\
\text { Formation }\end{array}$ & $\begin{array}{l}\text { Tuff of Wahmonie } \\
\text { Flat }\end{array}$ & Twlb & $\begin{array}{l}\text { Zeolitized bedded tuff } \\
\text { and tuffaceous } \\
\text { sandstone }\end{array}$ & \\
\hline Crater Flat Group & $\begin{array}{l}\text { Crater Flat Tuff, } \\
\text { undifferentiated }\end{array}$ & Tc & Zeolitized bedded tuff & \\
\hline Tunnel Formation & $\begin{array}{l}4 \text { Member and } \\
\text { older tuffs, } \\
\text { undifferentiated }\end{array}$ & $\mathrm{Tn} / \mathrm{To}$ & $\begin{array}{l}\text { Zeolitized ash-flow and } \\
\text { bedded tuffs }\end{array}$ & \\
\hline \multirow{3}{*}{$\begin{array}{l}\text { Volcanics of Oak } \\
\text { Spring Butte }\end{array}$} & Redrock Valley Tuff & Tor & $\begin{array}{l}\text { Nonwelded to partially } \\
\text { welded, devitrified to } \\
\text { zeolitized ash-flow tuff }\end{array}$ & \\
\hline & Tuff of Twin Peaks & Tot & $\begin{array}{l}\text { Nonwelded, devitrified } \\
\text { ash-flow tuff }\end{array}$ & \\
\hline & $\begin{array}{l}\text { Older tuffs, } \\
\text { undifferentiated }\end{array}$ & To & $\begin{array}{l}\text { Zeolitized and argillized } \\
\text { bedded tuff }\end{array}$ & \\
\hline Paleocolluvium & Paleocolluvium & $\mathrm{Tl}$ & $\begin{array}{l}\text { Gravel in calcareous, } \\
\text { clay-rich matrix; } \\
\text { tuffaceous beds }\end{array}$ & \\
\hline $\begin{array}{l}\text { Simonson } \\
\text { Dolomite }\end{array}$ & Simonson Dolomite & Ds & $\begin{array}{l}\text { Dolomite and dolomitic } \\
\text { quartzite }\end{array}$ & $\begin{array}{l}\text { Lower carbonate } \\
\text { aquifer }\end{array}$ \\
\hline
\end{tabular}

Source: Modified from IT (1995)

a Symbols by Ferguson et al. (1994).

b See Appendix B for detailed lithology and stratigraphy. 
Table 2-2

Depth to Selected Formation Tops and General

Drill Hole Information for Drill Holes U-3cn, U-3cn\#5, and U-3cn PS\#2

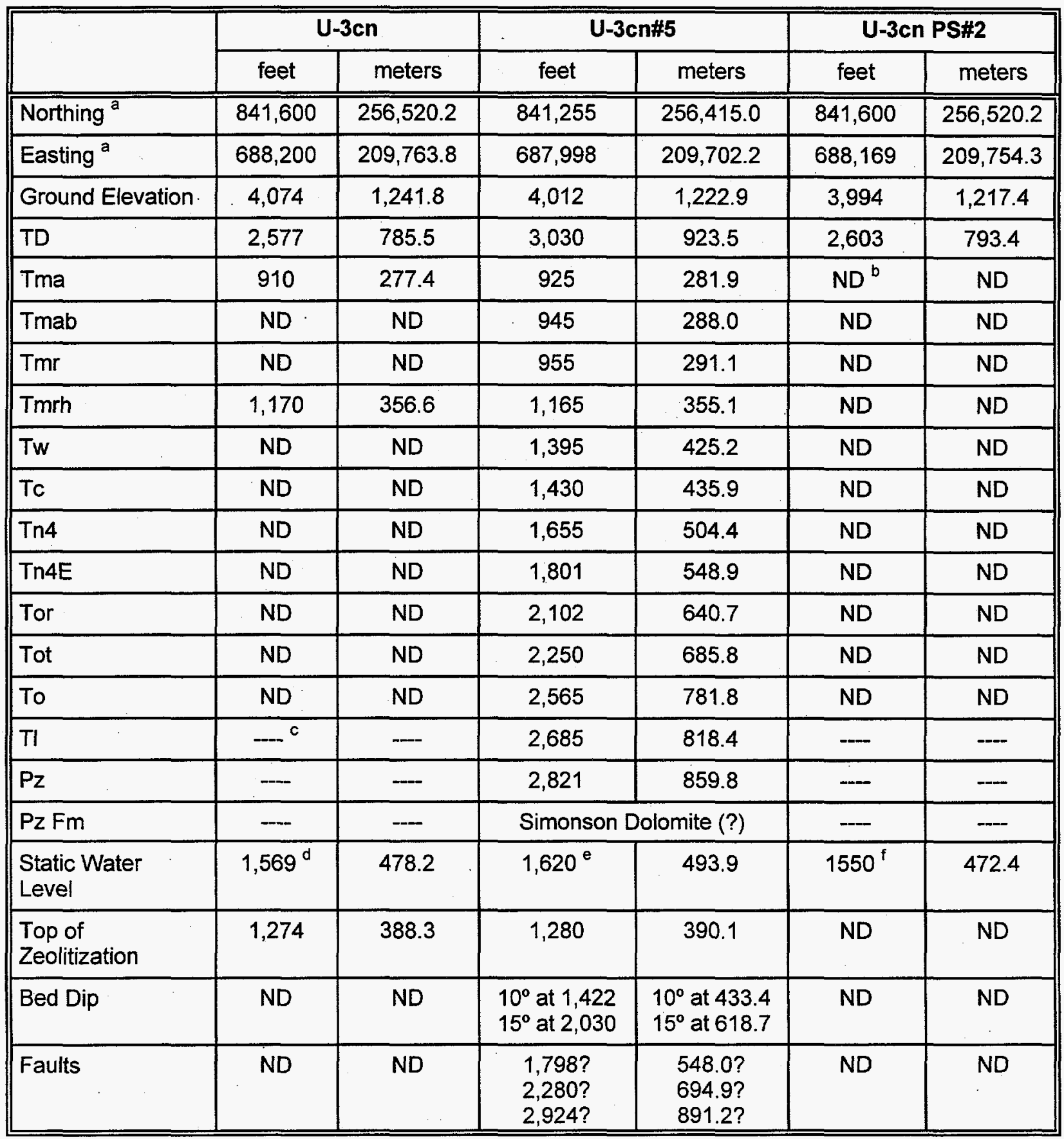

Source: Drellack and Thompson (1990).

See Table 2-1 for key to formation symbols.

a Central Nevada State Planar Coordinates

b Not defined.

c Formation not encountered.

d Garber and Johnston (1967)

e Measurement by USGS, December 1996 (Trudeau, 1997).

Fluid level from logs by Birdwell in 1977 (Arteaga et al. [1991]). 


\subsubsection{Results of Previous Hydrologic Investigations}

The local hydrology at the BILBY site was altered in the short term as a result of the explosion. As detailed in Hale et al. (1963), measurements made in nearby wells immediately after the explosion indicated that water levels rose significantly within the wells, presumably in response to the pressure pulse associated with displacement of rock around the shot point. Measurements in a nearby well that penetrated the underlying Paleozoic sedimentary rocks suggested that the rapid increase of hydraulic pressure also occurred within the lower carbonate aquifer as well. However, by the time water-level measurements could be made in Postshot Hole U-3cn PS\#2, two months after the explosion, the water level in the chimney rubble was approximately $96 \mathrm{~m}$ ( $315 \mathrm{ft}$ ) lower than the pre-test level. Measurements made in the postshot hole over the next several years indicated that it took approximately five years for the water level to recover to the pre-test level (Garber, 1971b; Buddemeier and Isherwood, 1985). Numerous fluid samples were collected from the postshot hole, and the chemistry data for these samples are listed in Beetem et al. (1965) and Garber (1971b), and summarized in Buddemeier and Isherwood (1985).

When last measured, the elevation of the water level in Hydrologic Test Hole U-3cn\#5,

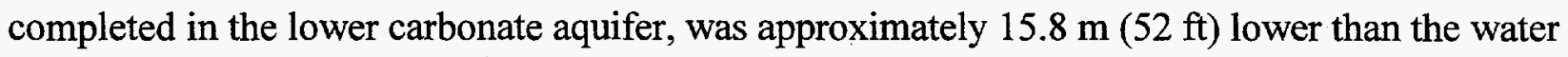
level in Postshot Hole U-3cn PS\#2, which did not penetrate the carbonate. This difference is consistent with the observation that fluid levels measured in wells completed in the lower carbonate aquifer are typically lower than wells completed in the tuff confining unit in Yucca Flat (Winograd and Thordarson, 1975).

During the drilling of Hydrologic Test Hole U-3cn\#5 radiation above background levels was observed on gamma and gamma-neutron logs in the interval 679.7 to $710.8 \mathrm{~m}(2,230-2,332 \mathrm{ft})$ (Garber and Johnston, 1967). It was determined at that time that the radionuclides were present along fracture planes in the welded tuff in this interval. Garber and Johnston (1967) ruled out radionuclide migration via groundwater because the hydraulic gradient at that time was away from the test hole, toward the chimney. They suggest that the radionuclides could have been emplaced by prompt injection at the time of the detonation. No radionuclides were found in fluids from this well during monitoring over the next ten years (Buddemeier and Isherwood, 1985). A summary of hydraulic tests conducted at Hydrologic Test Hole U-3cn\#5 is given in Table 2-3. 
Table 2-3

Summary of Hydraulic Tests at Hydrologic Test Hole U-3cn\#5

\begin{tabular}{|c|c|c|c|c|c|}
\hline $\begin{array}{l}\text { Depth Interval Tested } \\
\text { meters (m) (feet [ft]) }\end{array}$ & Date & $\begin{array}{l}\text { Stratigraphic } \\
\text { Unit }\end{array}$ & Lithology & $\begin{array}{l}\text { Hydrogeologic } \\
\text { Unit }\end{array}$ & $\begin{array}{l}\text { Specific } \\
\text { Capacity }\end{array}$ \\
\hline $\begin{array}{l}551.7 \text { to } 603.5 \mathrm{~m} \\
(1,810 \text { to } 1,980 \mathrm{ft})\end{array}$ & $\begin{array}{l}1965 \text { and } \\
1966\end{array}$ & Tn4E & $\begin{array}{l}\text { Ash-fiow tuff, } \\
\text { partially-welded, } \\
\text { zeolitized }\end{array}$ & TCU & \multirow{2}{*}{$\begin{array}{c}0.11 \mathrm{~m}^{2} / \mathrm{day} \\
0.006 \mathrm{gpm} / \mathrm{ft}^{\mathrm{c}} \\
\text { and } \\
0.18 \mathrm{~m}^{2} / \mathrm{day} \\
0.01 \mathrm{gpm} / \mathrm{ft}\end{array}$} \\
\hline $\begin{array}{l}603.5 \text { to } 655.3 \mathrm{~m} \\
(1,980 \text { to } 2,150 \mathrm{ft})\end{array}$ & $\begin{array}{l}1965 \text { and } \\
1966\end{array}$ & Tn, undiff. & $\begin{array}{l}\text { Ash-flow and } \\
\text { bedded tuffs, } \\
\text { zeolitized }\end{array}$ & TCU & \\
\hline $\begin{array}{l}670.6 \text { to } 726.9 \mathrm{~m} \\
(2,200 \text { to } 2,385 \mathrm{ft})\end{array}$ & $\begin{array}{l}1965 \text { and } \\
1966\end{array}$ & Tot & $\begin{array}{c}\text { Ash-flow tuff, } \\
\text { nonwelded to } \\
\text { moderately- } \\
\text { welded, zeolitized }\end{array}$ & TCU & $\begin{array}{l}0.11 \mathrm{~m}^{2} / \text { day } \\
0.006 \mathrm{gpm} / \mathrm{ft}\end{array}$ \\
\hline $\begin{array}{l}864.4 \text { to } 907.1 \mathrm{~m} \\
(2,836 \text { to } 2,976 \mathrm{ft})\end{array}$ & 1966 & $\mathrm{Pz}$ & $\begin{array}{l}\text { Mostly dolomite, } \\
\text { quartzite below } \\
892 \mathrm{~m}(2,925 \mathrm{ft})\end{array}$ & LCA & \multirow{2}{*}{$\begin{array}{l}7.2 \mathrm{~m}^{2} / \mathrm{day} \\
0.4 \mathrm{gpm} / \mathrm{ft}\end{array}$} \\
\hline $\begin{array}{l}864.4 \text { to } 922.9 \mathrm{~m} \\
(2,836 \text { to } 3,028 \mathrm{ft})\end{array}$ & 1966 & $\mathrm{Pz}$ & $\begin{array}{l}\text { Dolomite and } \\
\text { quartzite }\end{array}$ & LCA & \\
\hline
\end{tabular}

Source: Garber and Johnston (1967). Stratigraphy and lithology modified from Dixon et al. (1973) and Drellack and Thompson (1990).

a Tn4E - Tunnel Formation, 4 Member, Bed 4E; Tn-Tunnel. Formation 3 and 4 undifferentiated; Tot - Tuff of Twin Peaks;

$\mathrm{Pz}$ - Paleozoic rocks, undifferentiated

b TCU - Tuff-confining unit; LCA - Lower-carbonate aquifer

c Meter squared per day

Gallon per minute per foot of drawdown 
This Page Intentionally Left Blank. 


\subsection{Hydrologic Test Hole U-3cn\#5}

\subsection{Introduction}

The history of Well U-3cn\#5 is well documented, as described in Section 2 of this report. A synopsis of the drilling and original completion activities is given in the Bilby Recompletion Criteria Technical Letter (IT, 1995), where summaries of the original hydrologic studies are also provided. This section summarizes pertinent drilling data, describes how the recompletion was conducted, and presents the current status of the well.

\subsection{Activities Summary for Hydrologic Test Hole U-3cn\#5}

The drilling of Hydrologic Test Hole U-3cn\#5 in 1965/66 is summarized for the convenience of the reader in Section 3.2.1, and Section 3.2.2 describes the recent recompletion activities.

\subsubsection{Summary of Original Work}

Details of the drilling and original completion operations are documented in the hole history (F\&S, 1966a) and in Garber and Johnston (1967). The drilling of Hydrologic Test Hole U-3cn\#5 began in September 1965. The borehole was drilled and cored in several stages to a TD of $923.5 \mathrm{~m}$ (3,030 ft) using conventional drilling techniques, and was completed in February 1966 (the operation was prolonged due to a labor strike). Conductor casing with an outside diameter (od) of 20 in. was set at $11 \mathrm{~m}$ ( $36 \mathrm{ft})$, and drilling of a $44.5-\mathrm{cm}(171 / 2-\mathrm{in}$.) hole continued to $435.3 \mathrm{~m}(1,428 \mathrm{ft})$ where the drill bit assembly and two drill collars were lost. The hole was cemented and then side-tracked from 289.9 to $324.3 \mathrm{~m}$ (951-1,064 ft), leaving the lost tools in the hole. After drilling and coring reached the depth of $542.5 \mathrm{~m}(1,780 \mathrm{ft})$ the hole was again cemented (to $434.6 \mathrm{~m}[1,426 \mathrm{ft}]$ ) and redrilled to stop caving of the borehole. The $13 \% / 8$-in. casing was set from the surface to the depth of $432 \mathrm{~m}(1,418 \mathrm{ft})$, and the annulus of this casing was cemented from the bottom of the hole to the depth of $356.6 \mathrm{~m}(1,170 \mathrm{ft})$. The hole was then cored and reamed to $25.1 \mathrm{~cm}(97 / 8-\mathrm{in}$.) diameter to the depth of $609.6 \mathrm{~m}(2,000 \mathrm{ft})$ where it was discovered that borehole deviation had become severe (see Figure 3-1 for a plot of the borehole deviation). An effort was made to correct this by again cementing and redrilling the hole.

Coring and drilling continued to $731.5 \mathrm{~m}(2,400 \mathrm{ft})$, when drilling stopped for hydrologic testing. The hole was then opened to $31.1 \mathrm{~cm}\left(12 \frac{1}{4} \mathrm{in}\right.$.), and the 95/8-in. casing was set at $726.9 \mathrm{~m}$ $(2,385 \mathrm{ft})$. Its annulus was cemented, though not successfully. When drilling resumed, circulation was immediately lost so that further geologic data were obtained only by drilling sidewall and conventional cores. 


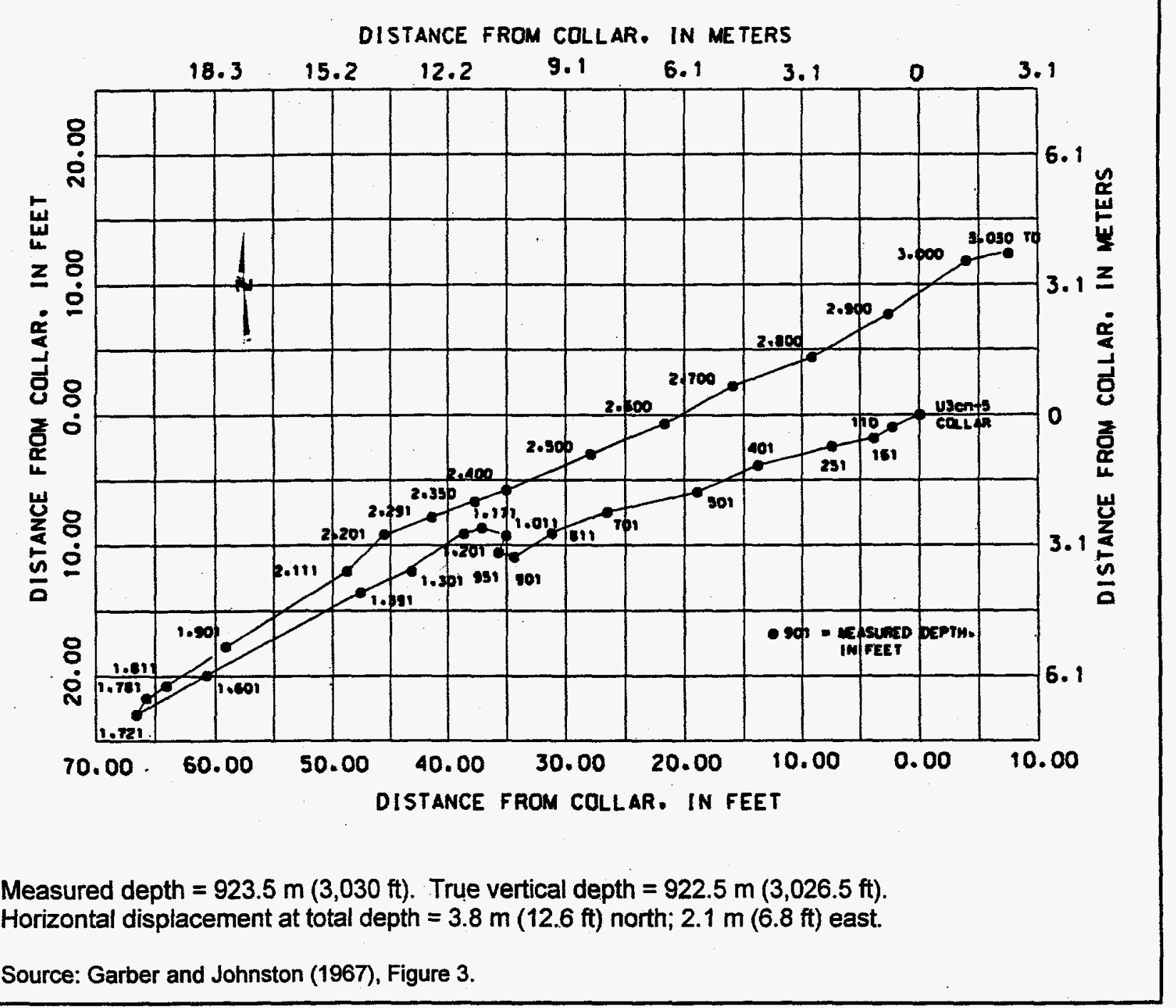

Source: Garber and Johnston (1967), Figure 3.

Figure 3-1

Graph of Directional Survey in Hydrologic Test Hole U-3cn\#5

It was verified by coring that at the depth of $863.2 \mathrm{~m}(2,832 \mathrm{ft})$ the hole had penetrated dolomitic limestone. To isolate the lower portion of the hole (after geophysical logging) a $65 / 8$-in. liner was hung from the $95 / 8$-in. casing to the depth of $863.2 \mathrm{~m}(2,832 \mathrm{ft})$, and the annulus of the lower part of the liner was cemented. Coring resumed, with pauses occasionally to obtain samples of the fluid from the Paleozoic rocks exposed in the open hole below the liner. After the hole reached TD in Paleozoic quartzite at the depth of $923.5 \mathrm{~m}(3,030 \mathrm{ft})$ in February 1966, additional hydraulic testing was conducted and a pump was installed. The pump was replaced in 1973 and again in.1976. The last pump failed in 1981. 


\subsubsection{Recompletion Activities}

No new drilling or logging was conducted for the Well U-3cn\#5 recompletion project. All field work was done on a one-shift-per-day basis (four ten-hour days per week). Information presented here was obtained from the BN NTS Daily Rig Operations reports. The daily recompletion activities for Hydrologic Test Hole U-3cn\#5 are listed in Appendix A-1, and Table 3-1 presents abridged drill hole statistics, incorporating the original drilling and casing data with the final recompletion configuration.

The BILBY site was prepared for the recompletion operation in December 1996, concurrently with preparations for activities at Postshot Hole U-3cn PS\#2. These preparations primarily consisted of construction of one lined sump and perimeter fences, dressing of existing roads and pads, and installation of work trailers, power, phones, and tanks for water and fuel. Replacement tubing in storage was cleaned and brought to the location in case it was needed.

A Franks 300 rig was set up over the wellhead on January 9, 1997 after discharge piping was removed to make room for it. After the drill crew made a few minor repairs and de-iced the equipment, the rig became operational on the afternoon of January 14, 1997. The uppermost $0.5 \mathrm{~m}(1.5 \mathrm{ft})$ of the $95 / \mathrm{z}-\mathrm{in}$. casing was cut off to permit access for removal of the pump string. It was verified that the pump string and access line were not attached to each other and that the pump was not attached to the bottom of the access line. The crew began to pull the pump string on January 15, 1997, leaving the access line in place.

Personnel donned anti-contamination clothing on January 16, 1997, after 50 joints of tubing had been removed, in anticipation of encountering contaminated fluid. A sample of fluid dripping from one of the joints was found to contain low levels of tritium, so a $3.8-\mathrm{cm}$ by $1.5-\mathrm{m}\left(1 \frac{1}{2}-\mathrm{in}\right.$. by 5 -ft) steel bar was dropped to open any bleeder valve that might be present within the tubing. Fluid subsequently drained from the tubing, thus reducing the chance of personnel contamination as the rest of the string was pulled. The bleeder valve and pump assembly were removed from the well and laid down on January 21, 1997. The joint above the old pump was found to be partially plugged with rust, and the suction screen was $90 \%$ plugged with rocks and pump debris.

A new Centrilift ${ }^{\mathrm{TM}}$ 50-HP tandem pump assembly was installed in the well. It was found that the wrong size suction screen had been sent with the pump, so in-stock pump screen was field-fitted to the pump intake opening. As the new pump was lowered into the well on the original tubing, each joint was examined for damage and rust. A total of 42 joints of old tubing were replaced 
Table 3-1

Abridged Drill Hole Statistics for Hydrologic Test Hole U-3cn\#5

\begin{tabular}{|c|c|c|}
\hline LOCATION DATA & $\begin{array}{l}\text { Coordinates: } \\
\quad \text { Central Nevada State Planar: } \\
\quad \text { Universal Transverse Mercator: } \\
\text { Ground elevation: } \\
\text { Distance from BILBY (Emplacement Hole } \\
\text { U-3cn): }\end{array}$ & $\begin{array}{l}\mathrm{N} 841,255, E 687,998 \mathrm{ft} \\
\mathrm{N} 4,101,713.7, \mathrm{E} 586,921.8 \\
\mathrm{~m} \\
1,222.9 \mathrm{~m}(4,012 \mathrm{ft}) \\
122 \mathrm{~m}(400 \mathrm{ft}) \text { on a bearing } \\
\text { of } \mathrm{S} 30.4^{\circ} \mathrm{W} \text { from } \mathrm{U}-3 \mathrm{cn}\end{array}$ \\
\hline \multicolumn{3}{|l|}{ DRILLING DATA } \\
\hline $\begin{array}{l}\text { Spud Date: } \\
\text { Completion Date: } \\
\text { Recompletion Date: } \\
\text { Total Depth (TD): } \\
\text { Hole Diameters: }\end{array}$ & \multicolumn{2}{|l|}{$\begin{array}{l}9-26-65 \\
2-9-66 \\
1-23-97 \\
923.5 \mathrm{~m}(3,030 \mathrm{ft}) \\
66.0-\mathrm{cm}(26-\mathrm{in} .) \text { hole to } 11 \mathrm{~m}(36 \mathrm{ft}) \\
44.5-\mathrm{cm}(171 / 2-\mathrm{in} .) \text { hole to } 435.3 \mathrm{~m}(1,4278 \mathrm{ft}) \\
31.1-\mathrm{cm}(121 / 4-\mathrm{in} .) \text { hole to } 731.5 \mathrm{~m}(2,400 \mathrm{ft}) \\
14.6-\mathrm{cm}\left(5^{3 / 4}-\mathrm{in} .\right) \text { hole to } 922.9 \mathrm{~m}(3,028 \mathrm{ft}) \\
13.0-\mathrm{cm}(51 / 8-\mathrm{in} .) \text { hole to } 923.5 \mathrm{~m}(3,030 \mathrm{ft})(\mathrm{TD})\end{array}$} \\
\hline Cores: & \multicolumn{2}{|c|}{$\begin{array}{l}\text { Conventional cores were cut in the following intervals: } 11 \text { to } 61 \mathrm{~m} \text { ( } 36 \text { to } \\
200 \mathrm{ft}) ; 518.2 \text { to } 731.5 \mathrm{~m}(1,700 \text { to } 2,400 \mathrm{ft}) ; 818.4 \text { to } 819.6 \mathrm{~m}(2,685 \text { to } \\
2,689 \mathrm{ft}) ; 861.7 \text { to } 863.2 \mathrm{~m}(2,827 \text { to } 2,832 \mathrm{ft} \text { ); and } 882.4 \text { to } 923.5 \mathrm{~m}(2,895 \\
\text { to } 3,030 \mathrm{ft}) \text {. Sidewall cores were also taken at various depths to supplemen } \\
\text { the above cored intervals (F\&S, 1966b; Garber and Johnston, 1967). }\end{array}$} \\
\hline $\begin{array}{l}\text { Drilling Problems } \\
\text { (1965/66): }\end{array}$ & \multicolumn{2}{|c|}{$\begin{array}{l}\text { Hole sloughing and lost circulation problems below about } 457.2 \mathrm{~m}(1,500 \mathrm{ft}) \text {; } \\
\text { poor core recovery. The hole was cemented back and redrilled three times } \\
\text { to sidetrack around lost drilling tools, to stop borehole caving, and to try to } \\
\text { straighten the hole. }\end{array}$} \\
\hline CASING DATA & \multicolumn{2}{|c|}{$\begin{array}{l}\text { 20-in. od conductor casing set at } 0 \text { to } 11 \mathrm{~m}(0-36 \mathrm{ft}) \\
133 / \text {-in. od casing set at } 0 \text { to } 432 \mathrm{~m}(0-1,418 \mathrm{ft}) \\
95 / 8 \text {-in. od casing set at } 0 \text { to } 727 \mathrm{~m}(2,385 \mathrm{ft}) \\
65 / 8 \text {-in. od liner set at } 707 \text { to } 863 \mathrm{~m}(2,321 \text { to } 2,832 \mathrm{ft})\end{array}$} \\
\hline \multicolumn{3}{|l|}{ WELL COMPLETION DATA } \\
\hline Open Borehole: & \multicolumn{2}{|l|}{$863.2 \mathrm{~m}$ to $923.5 \mathrm{~m}(2,832$ to $3,030 \mathrm{ft})(\mathrm{TD})$} \\
\hline Downhole Pump: & \multicolumn{2}{|c|}{$\begin{array}{l}\text { 50-horsepower Centrilift }{ }^{\mathrm{TM}} \text { tandem pump landed at } 691.3 \mathrm{~m}(2,268.1 \mathrm{ft}) \text { with } \\
\text { pump intake at } 687.6 \mathrm{~m}(2,255.8 \mathrm{ft}) \text {. Pump hangs on } 2^{7 / 8} \text {-in. od tubing inside } \\
\text { the } 95 \% \text {-in. casing. }\end{array}$} \\
\hline Access Line: & \multicolumn{2}{|l|}{$23 / 8$-in. od tubing set at 0 to $701.0 \mathrm{~m}(2,300 \mathrm{ft})$} \\
\hline Fluid Level $\left.\right|^{a_{\text {}}}$ : & \multicolumn{2}{|l|}{$493.9 \mathrm{~m}(1,620 \mathrm{ft})$} \\
\hline
\end{tabular}

Sources: F\&S (1966a); Garber and Johnston (1967); RSN (1991)

a Measured by USGS, December 1996 (Trudeau, 1997). 
with good, used, washed tubing. The pump was landed on January 23,1997 at the depth of $691.3 \mathrm{~m}(2,268.1 \mathrm{ft})$.

After the landing assembly for the pump string was welded onto the wellhead, a tubing manifold with a pressure gauge and valves was made up, and a flow line was connected. The pump was started mid-day on January 27, 1997, but was found to be running backward, so it was shut down, reversed, and restarted. The pump was found to work properly, and was allowed to run for approximately 42 minutes to flush any debris from the line; it was then shut down again to repair a small leak at the wellhead. Pumping and sampling then began at 1400 hours (hrs), and the crew began to disassemble the drill rig. The pump was allowed to run continuously while IT personnel collected fluid samples, until $1215 \mathrm{hrs}$ on January 29, 1997, when it was shut down after a total of approximately 46 hours pumping time.

Following pumping and sampling operations, the discharge hose and manifold were flushed with water tagged with lithium bromide. After the equipment was checked and found to be free of contamination, laborers removed the discharge line and other equipment.

\subsection{Fluid Management}

Effluent from Hydrologic Test Hole U-3cn\#5 was monitored as prescribed in the Fluid Management Plan for the Underground Test Area Operable Unit (DOE, 1994a). All fluids produced during pumping and sampling were routed to a lined sump. Information on the volumes and quality of fluids pumped for this project will be presented in a separate report.

\subsection{Hydrology}

The latest water-level data for Hydrologic Test Hole U-3cn\#5 were obtained in December 1996, when the depth to water was measured by the USGS at $493.9 \mathrm{~m}$ (1,620 ft) (Trudeau, 1997). No new hydrologic testing was conducted or fluid-level tags made during recompletion operations. Approximately 440 cubic meters $\left(\mathrm{m}^{3}\right)$ (116,346 gallons [gal]) of fluid were pumped from Hydrologic Test Hole U-3cn \#5 into the lined sump during this activity (BN, 1997).

Fluid samples from Hydrologic Test Hole U-3cn\#5 were taken during replacement of the pump string and pumping operations. The results of field analyses indicated tritium activities ranging from approximately 8,000 picoCuries per liter $(\mathrm{pCi} / \mathrm{L})$ for samples taken from the old equipment as it was drawn from the well, to near zero following pumping activities (BN, 1997). The results of analyses on these and other samples will be reported in a separate document. 


\subsection{Recompletion}

The recompletion undertaken at Hydrologic Test Hole U-3cn\#5 was planned to include only replacement of the existing pump and limited sampling. The goal of the operation was to provide for long-term monitoring of the quality of groundwater from the lower carbonate aquifer near the BILBY site. Figure 3-2 is a schematic of the final well-completion design for Hydrologic Test Hole U-3cn\#5, and Figure 3-3 shows a plan and profile view of the wellhead configuration.

\subsubsection{Planned Recompletion Design}

The recompletion design, as described in the Well Recompletion and Testing Program (BN, 1996), specified that the existing inoperable pump be replaced, with the intake of the new pump located at approximately the same depth as that of the old pump, $693.4 \mathrm{~m}(2,275 \mathrm{ft})$. The pump string was to be run without a check-valve so that water in the flowline will drain back into the well when the pump is turned off. The original tubing was to be used in the pump string, except that which must be replaced due to damage or excessive rust.

\subsubsection{As-Built Recompletion Design}

As described in the draft Bilby Recompletion Criteria Technical Letter (IT, 1995), a 22.7-cm (8.92-in.) inside-diameter (id) casing is cemented in the hole from the surface to the depth of $726.9 \mathrm{~m}(2,385 \mathrm{ft})$. A $15.0-\mathrm{cm}(5.92-\mathrm{in}$.) id liner, set in the hole from 707.4 to $863.2 \mathrm{~m}(2,321$ $2,832 \mathrm{ft}$ ), is attached to the $95 / 8$-in. casing with a lead seal, and its annulus cemented to isolate

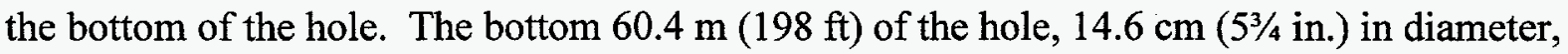
was originally left open to the dolomite formation. A $23 / 8$-in. access line was originally installed next to the pump string, and has been left in place. The new tandem pump was installed on $27 / 8$ in. carbon-steel tubing, with the intake at $687.6 \mathrm{~m}(2,255.8 \mathrm{ft})$. The string compositions are listed in Table 3-2 and tubing materials are given in Appendix A-2. 


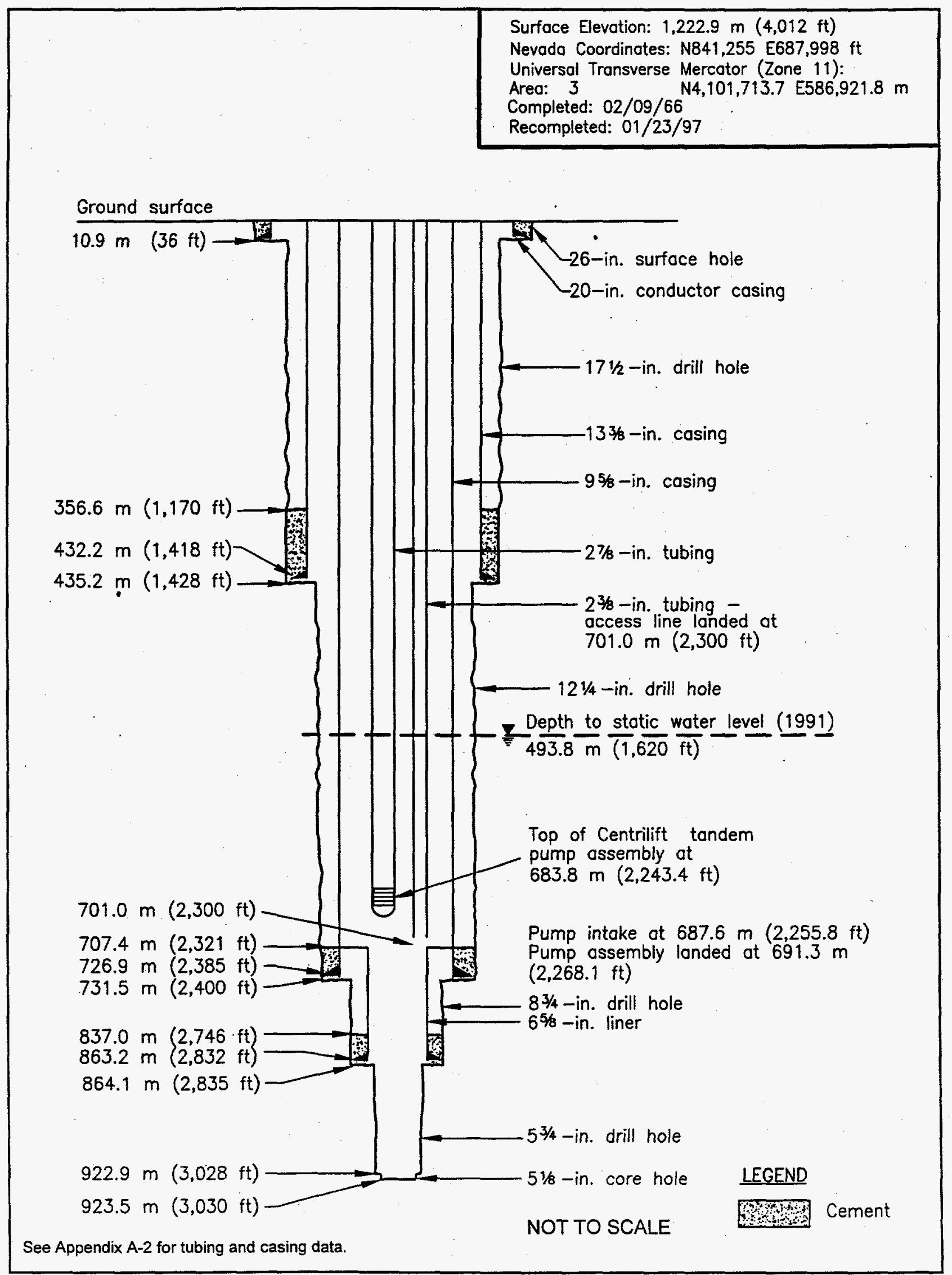

Figure 3-2

Recompletion Diagram for Hydrologic Test Hole U-3cn\#5 


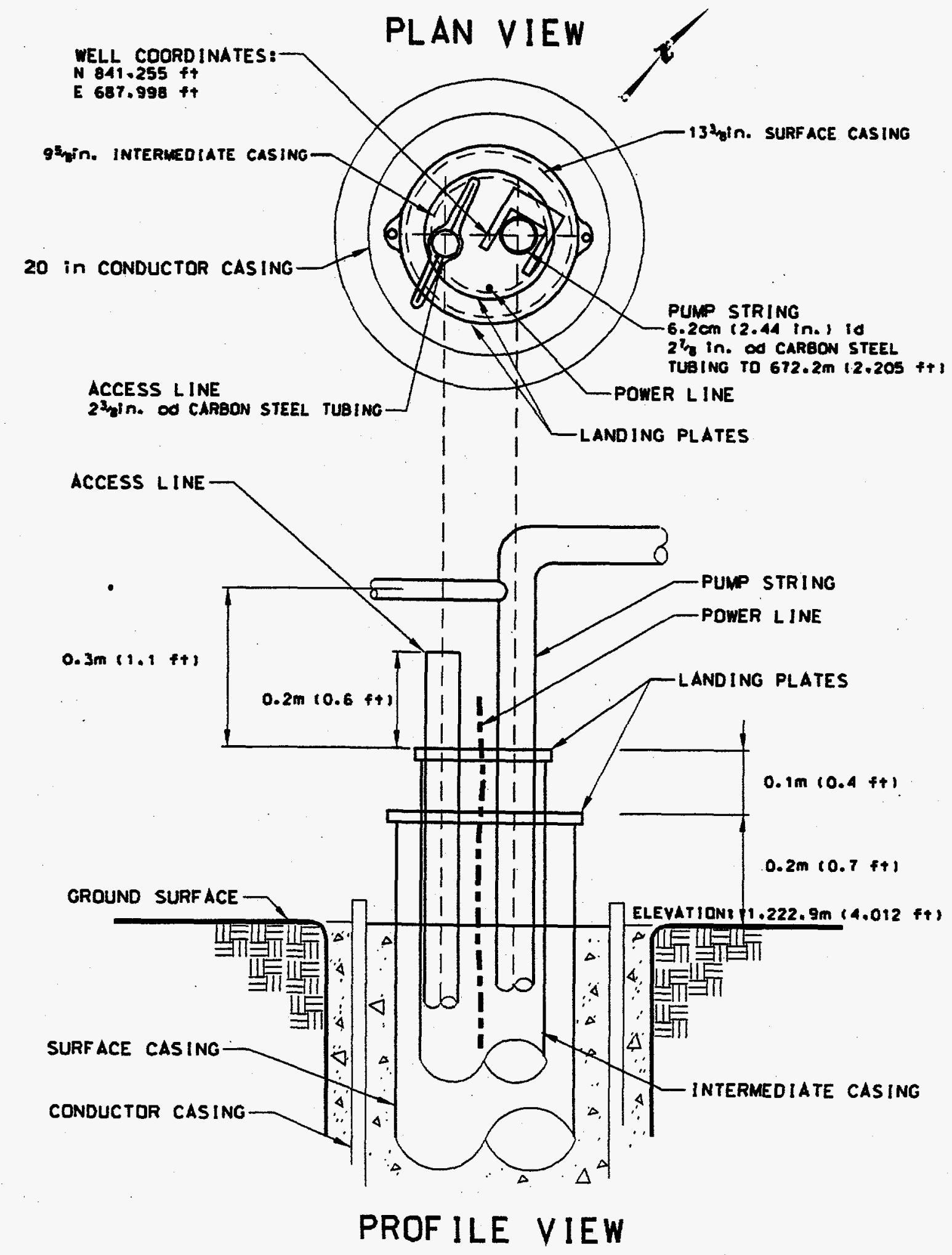

Figure 3-3

Wellhead Diagram for Hydrologic Test Hole U-3cn\#5 
Table 3-2

Hydrologic Test Hole U-3cn\#5 Construction Summary

\begin{tabular}{|c|c|c|}
\hline Completion String & Configuration & Cement $^{\mathrm{a}}$ \\
\hline 95/8-inch carbon-steel casing & $\begin{array}{l}\text { Ground surface to } 726.9 \mathrm{~m} \\
\qquad(2,385 \mathrm{ft})\end{array}$ & $\begin{array}{c}\text { Annulus tack-cemented } 708.1 \text { to } \\
731.5 \mathrm{~m}(2,323 \text { to } 2,385 \mathrm{ft})\end{array}$ \\
\hline 65/8-inch carbon-steel liner & $\begin{array}{c}\text { Attached to bottom of } 95 / 8 \text {-inch } \\
\text { casing with lead seal } \\
707.4 \text { to } 863.2 \mathrm{~m} \\
(2,321 \text { to } 2,832 \mathrm{ft}) \\
\end{array}$ & $\begin{array}{c}\text { Annulus cemented from } 837.0 \text { to } \\
863.2 \mathrm{~m} \\
(2,746 \text { to } 2,832 \mathrm{ft})\end{array}$ \\
\hline 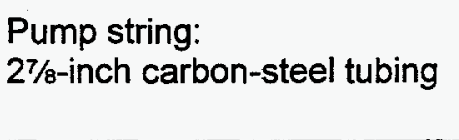 & $\begin{array}{l}\text { Inside } 95 / 8 \text {-inch casing/liner } \\
\text { Ground surface to } 683.8 \mathrm{~m} \\
\qquad(2,243.4 \mathrm{ft})\end{array}$ & Not cemented \\
\hline Pump Assembly: & \multirow[b]{2}{*}{$\begin{array}{c}683.8 \text { to } 687.6 \mathrm{~m} \\
(2,243.4 \text { to } 2,255.8 \mathrm{ft})\end{array}$} & \multirow{4}{*}{ Not cemented into well. } \\
\hline Tandem pumps & & \\
\hline Seal & $\begin{array}{c}687.6 \text { to } 689.5 \mathrm{~m} \\
(2,255.8 \text { to } 2,262.1 \mathrm{ft})\end{array}$ & \\
\hline Motor & $\begin{array}{c}689.5 \text { to } 691.3 \mathrm{~m} \\
(2,262.1 \text { to } 2,268.1 \mathrm{ft})\end{array}$ & \\
\hline $\begin{array}{l}\text { Access line: } \\
23 / 8 \text {-inch carbon-steel tubing }\end{array}$ & $\begin{array}{c}\text { Ground surface to } 701.0 \mathrm{~m} \\
(2,300 \mathrm{ft}) \\
\text { Bottom open }\end{array}$ & Not cemented into well. \\
\hline
\end{tabular}

Sources: F\&S (1966a); BN (1997)

a Precise cement compositions not available. 
This Page Intentionally Left Blank 


\subsection{Postshot Hole U-3cn PS\#2}

\subsection{Introduction}

The history of Postshot Hole U-3cn PS\#2 is well documented, as described in Section 2 of this report. A synopsis of the drilling and original completion activities is given in the Bilby Recompletion Criteria Technical Letter (IT, 1995), where summaries of the original hydrologic studies are also provided. This section briefly summarizes the original work conducted at Postshot Hole U-3cn PS\#2, documents the activities conducted for the BILBY recompletion project, and describes the current status of the well.

\subsection{Activities Summary for Postshot Hole U-3cn PS\#2}

The drilling of Postshot Hole U-3cn PS\#2 in 1963 is summarized for the convenience of the reader in Section 4.2.1, and Section 4.2.2 describes the current recompletion activities.

\subsubsection{Summary of Original Work}

Details of the drilling and original completion operations at this well can be found in the drill hole history (F\&S, 1966b) and in Garber (1971b). Drilling of Postshọt Hole U-3cn PS\#2 through the BILBY chimney began ten days after the detonation, in September 1963. A 103/4-in. casing was set in the $38.1-\mathrm{cm}(15-\mathrm{in}$.) borehole at $182.6 \mathrm{~m}(599 \mathrm{ft})$ and its annulus was cemented to the surface. Drilling of a 24.4-cm (95/8-in.) borehole continued to the TD of $793.4 \mathrm{~m}(2,603 \mathrm{ft})$, which was reached in October 1963. Several voids were encountered during drilling, but the use of heavy drilling mud apparently sealed off any gases (Garber, 1971b). Sidewall samples were taken from the interval 734.0 to $755.9 \mathrm{~m}(2,408-2,480 \mathrm{ft})$, just below the original WP. A diagram of the measured borehole deviation is given in Figure 4-1. A 41/2-in. casing was installed and perforated from near the estimated top of the explosion cavity to the hole TD. The fluid level was determined to be below $591.3 \mathrm{~m}(1,960 \mathrm{ft})$ during this operation. Radioactive gas was produced during perforating operations (Garber, 1971b).

Six days after perforation of the casing in Postshot Hole U-3cn PS\#2 measurements indicated that the casing had collapsed near the top of the perforated interval, presumably by shifting of blocks within the chimney rubble (Garber, 1971b). Hydrologic studies that continued at the well over the next eight months indicated that the fluid level was slowly rising (Garber, 1971b). In June 1964 a pair of packers was inserted into the casing to seal the casing above the damaged interval. The casing was perforated again above the packer, and a pump was installed. Pumping, sampling, and testing continued intermittently at the well through 1984, though the pump was 
DISTANCE FROM COLLAR, IN METERS

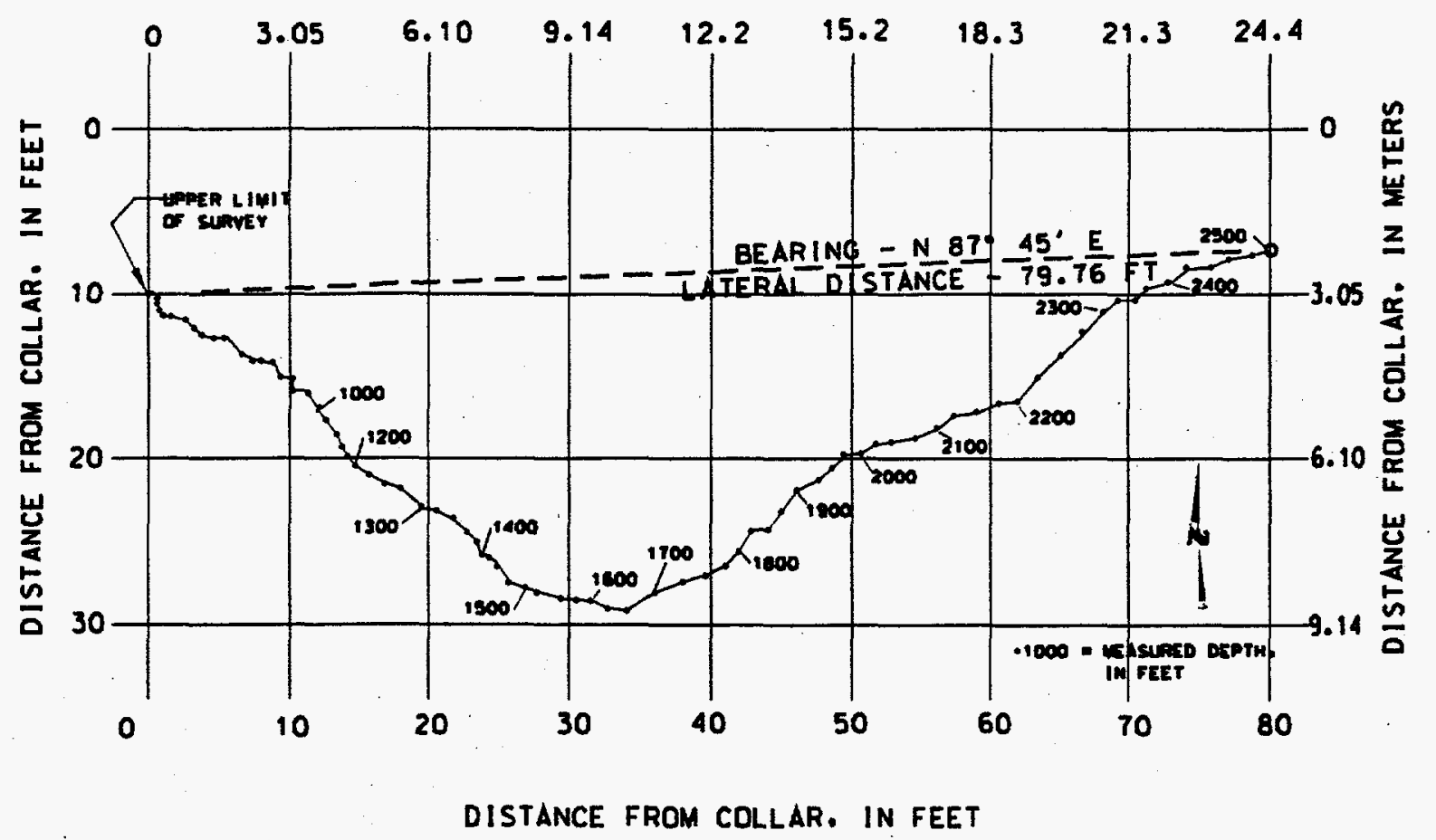

Measured depth at bottom of survey run $=762.0 \mathrm{~m}(2,500 \mathrm{ft})$.

True vertical depth at bottom of survey run $=761.3 \mathrm{~m}(2,497.8 \mathrm{ft})$.

Source: Garber (1971b), Figure 2.

\section{Figure 4-1}

Graph of Directional Survey in Postshot Hole U-3cn PS\#2

replaced in 1977. During pump replacement operations it was noted that the top of the $4 \frac{1}{2}$-in.

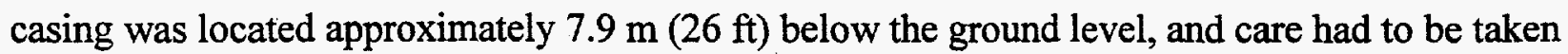
to assure that equiment lowered into the hole went into the casing rather than into the annulus (F\&S, 1977). The $1 / 2$-in. air line planned for use in making water-level tags was not run at that time (Ortego, 1977).

\subsubsection{Recompletion Activities}

No new drilling or logging was conducted for the Well U-3cn PS\#2 recompletion project. All field work was done on a one-shift-per-day basis (four ten-hour days per week). Information presented here was obtained from the BN NTS Daily Rig Operations reports. The daily recompletion activities for Postshot Hole U-3cn PS\#2 are listed in Appendix A-1, and Table 4-1 presents abridged drill hole and completion statistics. 
Table 4-1

Abridged Drill Hole Statistics for Postshot Hole U-3cn PS\#2

\begin{tabular}{|c|c|}
\hline $\begin{array}{l}\text { LOCATION DATA: } \\
\text { Coordinates: }\end{array}$ & $\begin{array}{ll}\text { Central Nevada State Planar: } & \text { N841,600, E688,169 ft } \\
\text { Universal Transverse Mercator: } & \text { N4,101,819.0, E586,973.6 m }\end{array}$ \\
\hline $\begin{array}{l}\text { Ground Elevation: } \\
\text { Distance from BILBY (U-3cn) }\end{array}$ & $\begin{array}{l}1,217.4 \mathrm{~m}(3,994 \mathrm{ft}) \\
9.4 \mathrm{~m}(31 \mathrm{ft}) \text { due west of Emplacement Hole U-3cn }\end{array}$ \\
\hline $\begin{array}{l}\text { DRILLING DATA: } \\
\text { Spud Date: } \\
\text { Completion Date: } \\
\text { Total Depth: } \\
\text { Hole Diameters: }\end{array}$ & $\begin{array}{l}9 / 23 / 63 \\
10 / 14 / 63 \\
793.4 \mathrm{~m}(2,603 \mathrm{ft}) \\
38.1-\mathrm{cm}(15-\mathrm{in} .) \text { diameter borehole to } 182.9 \mathrm{~m}(600 \mathrm{ft}) \\
24.4-\mathrm{cm}(95 / / \text {-in. }) \text { diameter borehole to } 562.7 \mathrm{~m}(1,846 \mathrm{ft}) \\
22.9-\mathrm{cm}(9-\mathrm{in} .) \text { diameter borehole to } 793.4 \mathrm{~m}(2,603 \mathrm{ft})\end{array}$ \\
\hline \multicolumn{2}{|r|}{$\begin{array}{l}10^{3 / 4} \text {-in. od casing set at } 182.6 \mathrm{~m}(599 \mathrm{ft}) \\
41 / 2 \text {-in. od casing (drill pipe) set at } 792.2 \mathrm{~m}(2,599 \mathrm{ft}) \text {. Top of casing } \\
\text { noted to be at } 7.9 \mathrm{~m}(26 \mathrm{ft}) \text { below surface in } 1977 .\end{array}$} \\
\hline \multicolumn{2}{|l|}{$\begin{array}{l}\text { WELL COMPLETION DATA: } \\
\text { Perforations: }\end{array}$} \\
\hline Downhole Pump: & $\begin{array}{l}\text { 10-horsepower Reda }{ }^{\mathrm{TM}} \text { submersible pump installed in September } \\
1977 \text { at } 509 \mathrm{~m}(1,670 \mathrm{ft}) \text { with pump intake at } 503.5 \text { to } 504.7 \mathrm{~m} \\
(1,652-1,656 \mathrm{ft}) \text {. Pump hangs on } 1 \% / 3 \text {-in. od tubing. }\end{array}$ \\
\hline Access Line: & None. One $1 / 2$-in. od access port is installed at the surface. \\
\hline Comments: & $\begin{array}{l}\text { Casing pinched or collapsed at } 587.0 \mathrm{~m}(1,926 \mathrm{ft}) \text { depth. A packer } \\
\text { is set at } 561.4 \mathrm{~m}(1,842 \mathrm{ft} \text { ) inside the } 41 / 2-\mathrm{in} \text {. casing, which isolates } \\
\text { the original perforations (at } 579.1 \text { to } 792.2 \mathrm{~m}[1,900-2,599 \mathrm{ft}]) \text { from } \\
\text { a second set, listed above. The condition of the pump was listed as } \\
\text { unknown in } 1984 \text { (Buddemeier and Isherwood, 1985) but was found } \\
\text { to operate adequately in January } 1997 \text {. }\end{array}$ \\
\hline Fluid Level ${ }^{\mathrm{a}}$ : & $472.4 \mathrm{~m}(1,550 \mathrm{ft})$ \\
\hline
\end{tabular}

Sources: F\&S (1966b); RSN (1991); Garber (1971b).

a Fluid level from logs by Birdwell in 1977 (Arteaga et al. [1991]).

The BILBY site was prepared in December 1996, as described in Section 3.2 of this report.

Other work conducted in preparation for work at Postshot Hole U-3cn PS\#2 included installation of an electrical panel for wiring of the pump and installation of hoses for discharge of fluids to the lined sump. 
The existing pump was successfully tested and allowed to run for 23 minutes on January 9, 1997. The next two days were spent preparing for the pumping test, as IT personnel rigged up and tested their equipment. Pumping began at $1600 \mathrm{hrs}$ on January 16, 1997 after time was spent that morning rigging up and thawing the flow lines. Sampling of fluid from the well began on Friday, January 17, 1997, and continued unit $1530 \mathrm{hrs}$ on January 22, 1997. The pump was allowed to run nearly continuously, for a total pumping time of approximately 140 hours.

Following the pumping and sampling, the discharge hose and manifold were flushed with water tagged with lithium bromide. After the equipment was checked and found to be free of contamination, laborers removed the discharge line and other equipment.

\subsection{Fluid Management}

Effluent from Postshot Hole U-3cn PS\#2 was monitored as prescribed in the Fluid Management Plan for the Underground Test Area Operable Unit (DOE, 1994a). All fluids produced during pumping and sampling were routed to a lined sump. Information on the volumes and quality of fluids pumped for this project will be presented in a separate report.

\subsection{Hydrology}

The most recent measured fluid level in Postshot Hole U-3cn PS\#2 was at $472.4 \mathrm{~m}(1,550 \mathrm{ft})$, as determined from geophysical logs in 1977 when the pump was replaced (Arteaga et al., 1991). No new hydrologic testing was conducted or fluid-level tags made during the 1997 recompletion operations at BILBY.

Approximately $286 \mathrm{~m}^{3}$ (75,514 gal) of fluid were pumped from the well in January 1997. Preliminary results of field analyses made on this fluid indicated tritium activities ranging from approximately 12.0 to 13.7 million $\mathrm{pCi} / \mathrm{L}(\mathrm{BN}, 1997)$. Final water-quality data will be presented in a separate report.High levels of tritium were detected in the early groundwater studies at Postshot Hole U-3cn PS\#2. Other radionuclides including ruthenium-106, cobalt-60, antimony125, cerium-144, and cesium-137 have also been detected. These data are summarized in Table 4-2. 
Table 4-2

Dissolved Radionuclides in Groundwater

Samples from Postshot Hole U-3cn PS\#2 (through 1965)

\begin{tabular}{|c|c|c|c|c|c|c|}
\hline Radionuclide & ${ }^{3} \mathrm{H}$ & ${ }^{106} \mathrm{Ru}$ & ${ }^{60} \mathrm{Co}$ & ${ }^{125} \mathrm{Sb}$ & ${ }^{144} \mathrm{Ce}$ & ${ }^{137} \mathrm{Cs}$ \\
\hline $\begin{array}{c}\text { Activity } \\
\text { (picocuries per liter) }\end{array}$ & $2.3 \times 10^{8}$ & 3,800 & 210 & 660 & 65 & 3 \\
\hline
\end{tabular}

Sources: Beetem et al. (1965) as summarized by Borg et al. (1976), Table 17.

\subsection{Recompletion}

\subsubsection{Planned Recompletion Design}

The recompletion project undertaken at Postshot Hole U-3cn PS\#2 was planned to include only replacement of the existing pump, if necessary, followed by pumping and limited sampling. The existing pump was found to be operable, so no equipment was removed from the well for examination or verification. Thus, the following section describes the existing completion configuration, as it is known from available records. Figure 4-2 is a schematic of the final wellcompletion design for Postshot Hole U-3cn PS\#2 and Figure 4-3 shows plan and profile views of the wellhead configuration.

\subsubsection{As-Built Completion Design}

As described in the original drill hole history (F\&S, 1966b), a 41/2-in. casing was installed from the surface to $792.2 \mathrm{~m}(2,599 \mathrm{ft})$ soon after drilling in 1963 . The $4 \frac{1}{2}-\mathrm{in}$. casing was perforated in October 1963, between the depths of 579.1 and $792.2 \mathrm{~m}(1,900-2,599 \mathrm{ft})$. However, it was soon found that the casing was collapsed or pinched at $587.0 \mathrm{~m}(1,926 \mathrm{ft})$. A pair of inflatable packers in tandem was installed in June 1965, with the top packer set at $561.4 \mathrm{~m}(1,842 \mathrm{ft})$. Additional perforations were made with a jet tool between 512.1 and $527.0 \mathrm{~m}(1,680-1,729 \mathrm{ft})$. Two 0.95$\mathrm{cm}(3 / 8-i n$.) diameter holes were made per foot of casing (Garber, 1971b). The existing 10-HP Reda $^{\mathrm{TM}}$ pump was installed new in 1977. It was lowered on a string of $12 / 3$-in. tubing to $509.3 \mathrm{~m}$ $(1,670.8 \mathrm{ft})$, with its intake at 503.5 to $504.7 \mathrm{~m}(1,652-1,656 \mathrm{ft})$. No access line is believed to be installed in the well, though a $1 / 2$-in. access port is visible at the wellhead. The string composition is listed in Table 4-3, and tubing materials are given in Appendix A-2 


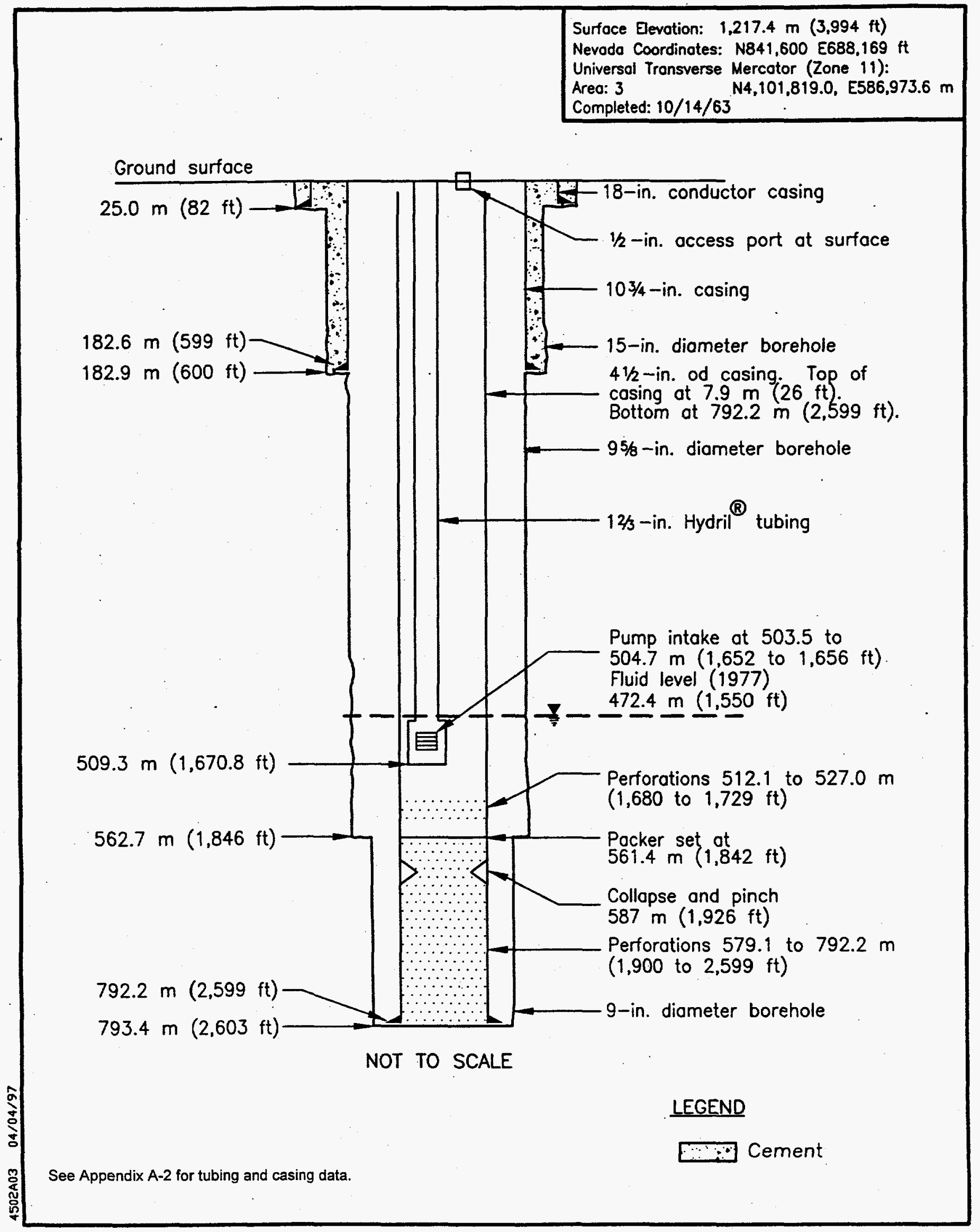

Figure 4-2

Completion Diagram for Postshot Hole U-3cn PS\#2 


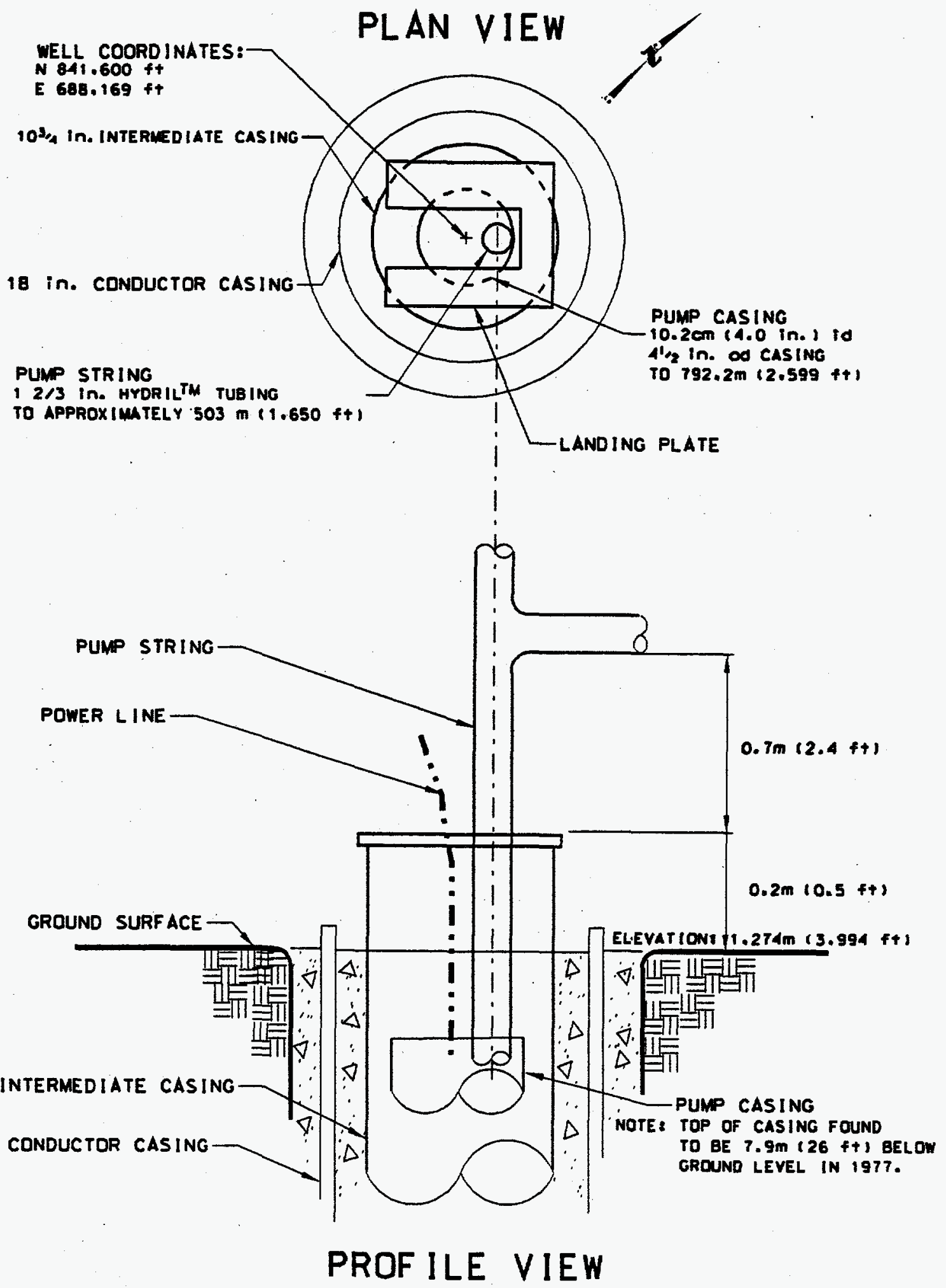

Figure 4-3

Wellhead Diagram for Postshot Hole U-3cn PS\#2 
Table 4-3

Postshot Hole U-3cn PS\#2 Construction Summary

\begin{tabular}{||l|c|c||}
\hline \multicolumn{1}{|c|}{ Completion String } & Configuration & Cement \\
\hline \hline $41 / 2$-inch casing & $\begin{array}{c}7.9 \text { to } 792.2 \mathrm{~m}(26 \mathrm{fo} 2,599 \mathrm{ft}) \\
\text { Top of packer at } 561.4 \mathrm{~m}(1,842 \mathrm{ft}) \\
\text { Perforated at } 512.1 \text { to } 527.0 \mathrm{~m}(1,680 \text { to } 1,729 \mathrm{ft})\end{array}$ & Not cemented \\
\hline $\begin{array}{l}12 / 3 \text {-inch Hydril } \\
\text { Installed inside 41/2-inch } \\
\text { casing }\end{array}$ & $\begin{array}{c}\text { Ground surface to approximately } 502.9 \mathrm{~m}(1,650 \mathrm{ft}) \\
10-\mathrm{HP} \text { pump hanging on end of tubing, with its intake } \\
\text { at } 503.5 \text { to } 504.7 \mathrm{~m}(1,652 \text { to1,656 ft) }\end{array}$ & Not cemented \\
\hline
\end{tabular}

Sources: F\&S (1966b; 1977); BN (1997) 


\subsection{Summary, Recommendations, and Lessons Learned from the BILBY Recompletion Operation}

\subsection{Summary}

BILBY $(\mathrm{U}-3 \mathrm{cn})$ was the first underground nuclear test conducted below the water table at the Nevada Test Site, and numerous studies were conducted in the 1960 s and 1970 s to determine the effects of the explosion on the groundwater. Several holes were drilled to study the near-field hydrology of the BILBY site, and two of these were evaluated for recompletion in January 1997. Hydrologic Test Hole U-3cn\#5 had been drilled approximately $40 \mathrm{~m}(130 \mathrm{ft})$ from the edge of the chimney, into the regional carbonate aquifer, and Postshot Hole U-3cn PS\#2 had been drilled within the collapse-chimney rubble. The original studies conducted through years of pumping and sampling these wells demonstrated that the groundwater table dropped locally as an immediate result of the explosion, but recovered to near pre-test levels in about five years. In addition, after pumping for more than ten years on the hydrologic test hole, which remained open to the lower carbonate aquifer, no radionuclides were found to have migrated outside the collapse chimney. However, due to the nature of these early tests and because of the time that has passed since either hole was sampled, scientists could not rule out the possibility that some radionuclides might have migrated into the lower carbonate aquifer. The positions of these two holes and the abundance of data available for the site made the BILBY site an ideal location for nearfield monitoring studies. The Technical Working Group determined that valuable information about radionuclide migration might be obtained simply by replacing well hardware and monitoring groundwater quality, so the two holes were targeted for recompletion.

Hydrologic Test Hole U-3cn\#5 is cased to the depth of $863 \mathrm{~m}(2,832 \mathrm{ft})$, with the lower $60.4 \mathrm{~m}$ (198 ft) of the hole open to Paleozoic-age sedimentary rocks of the lower carbonate aquifer. The existing inoperable pump was replaced with a new 50-HP tandem pump in January 1997. The existing open-ended access line was left in place. This pump was operated for 46 hours and groundwater samples were taken for analysis.

Postshot Hole U-3cn PS\#2 was drilled in the BILBY collapse chimney rubble. The existing pump was found to be operable, but there appears to be no access line for water-level tags. The borehole is fully cased, but a packer isolates a $15-\mathrm{m}(49-\mathrm{ft})$ perforated section that is open only to the rubble above the original explosion cavity, but below the water table. The pump in the postshot hole, originally installed in 1977 and last operated in 1984, was run for 140 hours in January 1997. Groundwater samples were taken for analysis. 
No new drilling or geophysical logging was conducted for the BILBY recompletion project, but the geologic characteristics of the site are well known from previous studies. Figure 5-1 illustrates the site geology, the BILBY collapse chimney, and the two wells, showing the positions of the pump intakes and the portions of the holes that are open to the surrounding medium.

Samples of fluid from both holes were analyzed for tritium at the site during the recompletion project. Only very low levels of tritium were encountered in Hydrologic Test Hole U-3cn \#5, and these dropped to near zero during pumping. Tritium activity of approximately 12.0 to 13.7 million $\mathrm{pCi} / \mathrm{L}$ was encountered in fluid from Postshot Hole U-3cn PS\#2.

\subsection{Recommendations for Additional Data Interpretation}

No plans exist at this time for additional interpretation of data from the BILBY site. The site remains available for future groundwater monitoring operations.

\subsection{Lessons Learned}

Although no drilling or testing was conducted at BILBY for this project, the work conducted for this recompletion project offers a few lessons for future operations, as listed below:

- Construction of the lined sump (estimated to take two weeks) was conducted over several weeks because sufficient labor resources were not available when work began. This intermittent work schedule resulted in lost efficiency, including extra travel time for numerous short work periods and time spent waiting for crews when the start of one operation was dependent on the completion of another. In the future, work should not begin until full resources are available to provide a continuous work force to complete the job.

- This operation provided a rare opportunity to inspect an old monitoring well. Evaluation of this information might provide insight to ways of improving the construction designs of long-term monitoring wells constructed in support of the DOE Environmental Restoration Program.

- Although significant data on the hydrology of nuclear test areas were obtained over a period of nearly twenty years at BILBY, it was still difficult to find and verify the most recent construction data for the wells at this site. As already begun for other UGTA projects, the effort to document all field activities adequately must continue. 


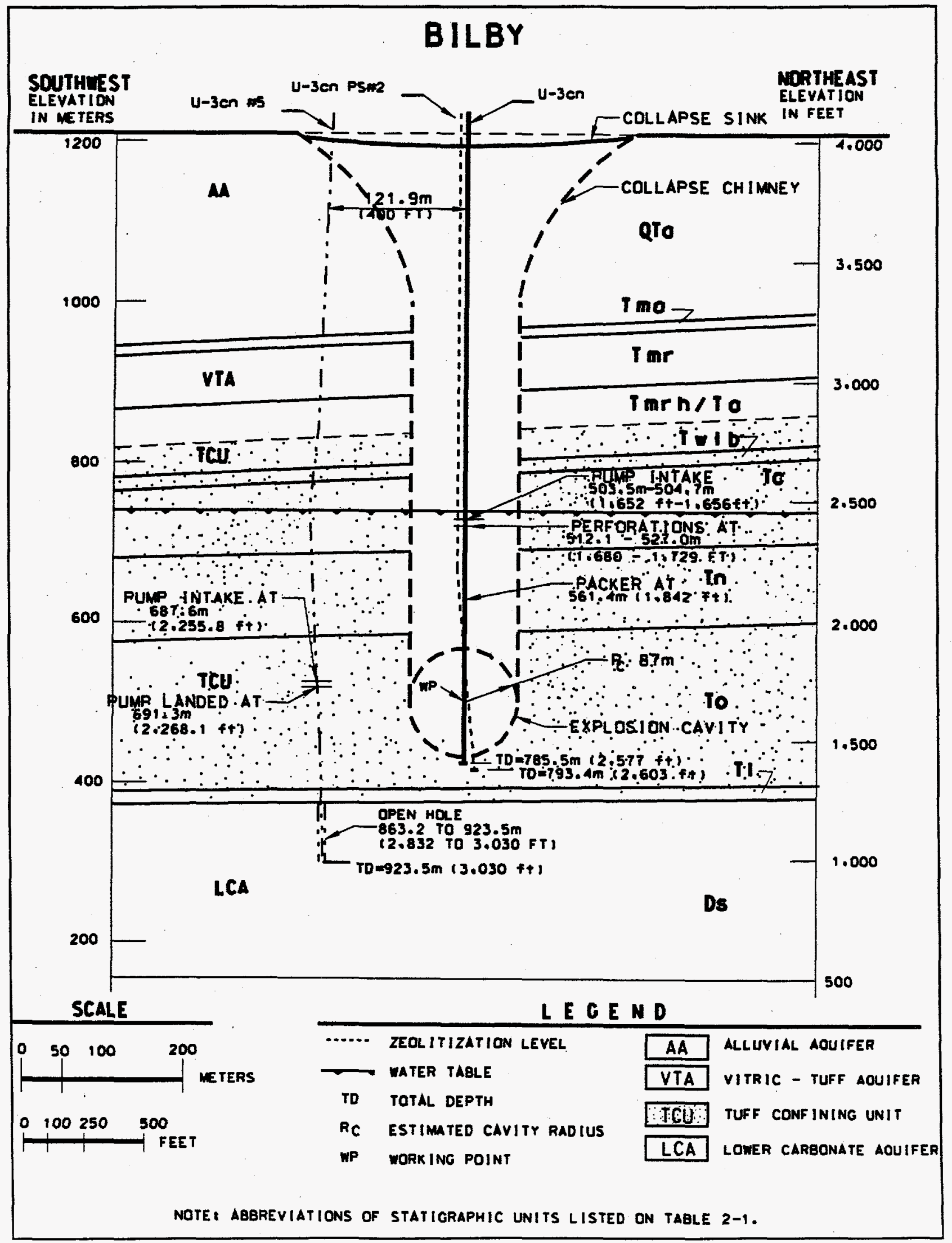

Figure 5-1

Southwest-Northeast Diagrammatic Cross Section Through BILBY and Hydrologic Test Hole U-3cn\#5 
This Page Intentionally Left Blank. 


\subsection{References}

Arteaga, F.E., C.S..Savard, M.E. Johnson, and J.C. Stone, 1991. Hydrogeologic Data from Selected Wells and Test Holes In and Adjacent to the Nevada Test Site, Nye County, Nevada, Through 1986. U.S. Geological Survey Open-File Report 87-536.

BN, see Bechtel Nevada.

Bechtel Nevada, 1996. Well Recompletion and Testing Program for Underground Test Area Operable Unit (UGTA OU) Well U-3cn\#5 and U-3cn PS\#2, Drilling Program D-012-011.96, Mercury, NV.

Bechtel Nevada, 1997. Nevada Test Site Daily Rig Operations Reports, U-3cn\#5 and U-3cn PS\#2, Mercury, NV.

Beetem, W.A., C.G. Angelo, and B.P. Robinson, U.S. Geological Survey, 1965, Quality of Water Studies at the Bilby Site, Technical Letter NTS-113. Denver, CO.

Borg, I.Y., R. Stone, H.B. Levy, and L.D. Ramspott; Lawrence Livermore National Laboratory, 1976. Information Pertinent to the Migration of Radionuclides in Groundwater at the Nevada Test Site, Part I: Review and Analysis of Existing Information, UCRL-52078, Part 1, p. 216. Livermore, CA.

Brikowski, T.H., 1991. The Hydrology of Underground Nuclear Tests: The Effect of CollapseChimney Formation. Desert Research Institute Publication \#45090, DOE/NV/10845-10, UC-703. Las Vegas, NV.

Buddemeier, R.W. and D. Isherwood, 1985. Radionuclide Migration Project 1985 Progress Report, Lawrence Livermore National Laboratory Report UCRL-5362B. Livermore, CA.

Dixon, G.L., K.A. Sargent, and R.W. Spengler, 1973. Lithologic Logs and Stratigraphic Identification of Exploratory and Emplacement Drill Holes in Area 3, Nevada Test Site. U.S. Geological Survey Report USGS-474-151 (NTS-244). Denver, CO.

DOE, see U.S. Department of Energy.

Drellack, S.L, Jr., and P.H. Thompson, 1990. Selected Stratigraphic Data for Drill Holes in LANL Use Areas of Yucca Flat, NTS. Fenix \& Scisson of Nevada Report DOE/NV/1032239. Mercury, NV.

F\&S, see Fenix \& Scisson, Inc.

Fenix \& Scisson, Inc., 1966a. Hole History Data, U-3cn \#5. This report may be obtained from Bechtel Nevada, Mercury, NV. 
Fenix \& Scisson, Inc., 1966b. Hole History Data, U-3cn PS \#2, Revision 1. This report may be obtained from Bechtel Nevada, Mercury, NV.

Fenix \& Scisson, Inc., 1977. Daily Drilling Report, U-3cn PS\#2. This report may be obtained from Bechtel Nevada, Mercury, NV.

Ferguson, J.F., A.H. Cogbill, and R.G. Warren, 1994. A Geophysical-Geological Transect of the Silent Canyon Caldera Complex, Pahute Mesa, Nevada. Journal of Geophysical Research, v. 99 , n. 33 , pp. 4323-4339.

Garber, M.S., 1971a. A Method for Estimating Effective Porosity in a Rubble Chimney Formed by an Underground Nuclear Explosion. U.S. Geological Survey Professional Paper 750-C, pp. C207-C209.

Garber, M.S., 1971b. Hydraulic-Test and Quality-of-Water Data from Hole U-3cn PS\#2, Bilby Site, Nevada Test Site, U.S. Geological Survey Report USGS-474-102 (NTS-230). Denver, $\mathrm{CO}$.

Garber, M.S. and R.H. Johnston, 1967. A Summary of Lithologic Data, Aquifer Tests, and Construction of Hydraulic Test Well U-3cn\#5, Nevada Test Site. U.S. Geological Survey Technical Letter NTS-200. Denver, CO.

Hale, W.E., I.J. Winograd, and M.S. Garber, 1963. Preliminary Appraisal of Close-in Aquifer Response to the Bilby Event, Yucca Flat, Nevada. U.S. Geological Survey Technical Letter NTS-63. Denver, CO.

IT, see IT Corporation.

IT Corporation, 1995. Bilby Recompletion Criteria Technical Letter. Draft prepared for DOE/NV. Las Vegas, Nevada.

Laczniak, R.J., J.C. Cole, D.A. Sawyer, and D.A. Trudeau, 1996. Summary of Hydrogeologic Controls on the Movement of Groundwater at the Nevada Test Site, Nye County, Nevada. U.S. Geological Survey Water Resources Investigations Report 96-4109. Carson City, NV.

McCall, R.L., Raytheon Services Nevada, 1994, BM4 West-East Geologic Cross Section Through UE-1q and Along Northing $841,500 \mathrm{ft}$, Scale 1:12,000, 1 sheet. Available from BN Geology, Mercury, NV.

Ortego, P.K., 1977. Fenix \& Scisson, Inc. Record of Verbal Communication dated August 26, 1977 concerning pump replacement at Well U-3cn PS\#2. Mercury, NV.

Raytheon Services Nevada, 1991. Drilling and Mining Summary (through December 1990), Mercury, Nevada.

RSN, see Raytheon Services Nevada. 
Trudeau, D. U.S. Geological Survey. January 27, 1997. Letter to Doug Duncan, DOE, regarding hydrologic data collection at the NTS. Las Vegas, NV.

U.S. Department of Energy, 1994a. Fluid Management Plan for the Underground Test Area Operable Unit, DOE/NV--370, UC-600. Las Vegas, NV.

U.S. Department of Energy, 1994b. United States Nuclear Tests, July 1945 through September 1992. Report DOE/NV-209 (Rev. 14). Las Vegas, NV.

Williams, W.P., 1964. Surface Effects of the Bilby Event, U-3cn Site, September 1963, Area 3, Yucca Flat, Nevada Test Site. U.S. Geological Survey Technical Letter NTS-68. Denver, $\mathrm{CO}$.

Williams, W.P. and D.L. Hoover, 1963. The Lithology of the U-3cn Drill Hole Site, Area 3, Nevada Test Site. U.S. Geological Survey Technical Letter Yucca-50. Denver, CO.

Winograd, I.J. and W. Thordarson, 1975. Hydrogeologic and Hydrochemical Framework, South-Central Great Basin, Nevada-California, with Special Reference to the Nevada Test Site. U.S. Geological Survey Professional Paper 712-C. 
This Page Intentionally Left Blank. 


\section{Appendix A Completion and Recompletion Data}

A-1 Recompletion Histories for Hydrologic Test Hole U-3en\#5 and Postshot Hole U-3en PS\#2

A-2 Casing and Tubing Data for Hydrologic Test Hole U-3cn\#5 and Postshot Hole U-3cn PS\#2 
This Page Intentionally Left Blank. 
Appendix A-1

Recompletion Histories for Hydrologic Test Hole U-3cn\#5 and Postshot Hole U-3cn PS\#2 
This Page Intentionally Left Blank. 
Table A-1-1

Hydrologic Test Hole U-3cn\#5 Recompletion History

All work was conducted on 10-hours-per-day, 4-days-per week basis.

Source: Bechtel Nevada NTS Daily Rig Operations Reports

Activities at the BILBY site common to both Hydrologic Test Hole U-3cn\#5 and Postshot Hole U-3en PS\#2:

$\begin{array}{lll}\text { Date } & \text { Day } & \text { Activity } \\ 11-6-96 & (1) & \text { Begin work on site construction: road dressing, etc. } \\ 11-7-96 & (2) & \text { Work on Sump \#1 excavation. } \\ 11-12-96 & (3) & \text { Work on Sump \#1 excavation. } \\ 11-13-96 & (4) & \text { Work on Sump \#1 excavation } \\ 11-14-96 & (5) & \text { Work on Sump \#1 excavation. } \\ 11-18-96 & (6) & \text { Work on Sump \#1 excavation. } \\ 11-19-96 & (7) & \text { Work on Sump \#1 excavation. Sand hauled to line sump. } \\ 11-20-96 & (8) & \text { Work on Sump \#1 excavation } \\ 11-21-96 & (9) & \text { Begin digging sump liner trench. } \\ 11-25-96 & (10) & \text { Installing sand in liner trench; plastic liner delivered. } \\ 11-26-96 & (11) & \text { Installing sand in liner trench; dig "diverter" trench. } \\ 12-2-96 & (12) & \text { Install 40-mil liner in Sump \#1; backfill trench to secure liner; install escape } \\ 12-3-96 & (13) & \text { Construct fences, dress road, build pads for parking, trailers, generators, etc. } \\ 12-4-96 & (14) & \text { Finish fences. } \\ 12-5-96 & (15) & \text { Build generator pad; work on parking area. Build perimeter fence for exclusion } \\ & & \text { zone around U-3cn\#5 and U-3cn PS\#2. }\end{array}$

\section{Activities at Hydrologic Test Hole U-3cn\#5:}

\section{Date Day Activity}

$12-9-96$

(16) Rig up and auger-drill 35.5-centimeter (14-inch [in]). anchor hole to 3 meters (m) (10 feet $[\mathrm{ft}$ ). Finish work on pads and parking.

$12-10-96$

(17) Install anchor for Franks 300 rig. Move rig to location. Complete perimeter fences.

$12-11-96$

(18) Cut, place, and secure 40-mil plastic protective sheet. Park rig on sheet.

12-12-96 (19) Subdock crew lays out 70 joints $( \pm 640.1 \mathrm{~m}[2,100 \mathrm{ft}])$ of $27 / 8$-in. $8 \mathrm{Rd}$ tubing and 120 joints $( \pm 1,097.3 \mathrm{~m}[3,600 \mathrm{ft}])$ of 1.6-in. Hydril tubing for cleaning as time permits.

12-18-96

(20) Transport equipment from ER-20-6 site. Set up water tank.

Operation shut down for holidays, 12-19-96 through 1-5-97.

$1-6-97$

(21) Continue site preparation (fencing, field offices, phone lines, etc.). 
Hydrologic Test Hole U-3cn\#5 Recompletion Activities, continued.
Date
Day
Activities
$1-7-97$
(22) Continue site preparation
$1-8-97$
Fencing continues; continue wiring transportainers; lay out discharge hoses from sump to well.

$1-9-97$

$1-14-97$

$1-15-97$

$1-22-97$

$1-27-97$

Continue wiring up support buildings. Remove insulation and discharge piping from wellhead. Spot rig over well; begin rigging up. Tubing determined not to be tied together. Lay down 35 joints $( \pm 324.6 \mathrm{~m}[ \pm 1,065 \mathrm{ft}])$ of $27 / 8$-in. tubing.

De-ice and repair rig. Rig operational at 1530 hours (hrs).

Cut $0.5 \mathrm{~m}(1.5 \mathrm{ft})$ off $95 / 8$-in. casing to lower the $27 / 8$-in. pump string and monitoring string to a workable level for the removal of the pump string. The two strings of tubing not attached together.

Lay down Joints \#36-50 of 27/8-in. pump string. Don anti-Cs; continue pulling tubing. Fluid leaking from Joint \#52 is sampled and tritium level found to be 4,800 disintegrations per minute. Drop 3.8-centimeter by $1.5-\mathrm{m}(1.5-\mathrm{in}$. by 5 -ft) steel bar to open bleeder valve down hole; fluid drains from pipe. Lay down tubing Joints \#53-70. Lay down bleeder valve. Lay down full Joint \#71 and disconnect electric cable. Land pump assembly in the hole on the 5-ft pup joint.

Continue laying down pump assembly. Joint above pump partially plugged with rust; suction screen $90 \%$ plugged with rocks and pump debris. Lay out and measure pump string.

Pick up new 50-horsepower Centrilift ${ }^{\mathrm{TM}}$ pump; assemble tandem pump assembly. Screen shipped with pump too small; welder spot welds a suction screen to the pump and seals flanges. Pick up and run $27 / 8$-in. tubing, hitting joints with hammer to check for rust. Run pump on same (to Joint \#19 at $443 \mathrm{ft}$ ). Lay down Joint \#6 due to excessive rust inside.

Continue running pump. Lay down Joints \#32, \#35, and \#38-55 due to excessive rust. Replace Joints \#38-79 with good used, washed tubing. Strip on landing plate and land pump with bottom at $691.3 \mathrm{~m}(2,268.1 \mathrm{ft})$. IT Corporation (IT) personnel and laborers rigging up discharge flowline to sump and rigging up "sample manifold." Construct "mini sumps" under each connection.

Welder fabricates $27 \%$-in. tubing landing assembly on wellhead. Make up tubing manifold; connect flowline. IT completes installation of flow monitoring equipment. Start pump at $1127 \mathrm{hrs;}$ determine that it is running backwards. Shut down at $1139 \mathrm{hrs}$ and reverse pump; restart at $1147 \mathrm{hrs}$; fluid to surface in 5 minutes. Small leak at wellhead sampled by RadSafe. Shut down pump at 1229 hrs after running flow directly into sump to flush any debris from line. Repair leak at wellhead. Restart pump at $1351 \mathrm{hrs}$. Fluid to surface in 5 minutes. Pumping and sampling test begins at $1400 \mathrm{hrs}$. Rig down Franks rig. IT allows flow to go into sump, waiting for it to clear before running it through flowmeter. Fluid directed through flowmeter at $1517 \mathrm{hrs}$ though still rusty in color (41 gallons per minute [gpm]). Electricians move equipment out. 
Hydrologic Test Hole U-3cn\#5 Recompletion Activities, continued.

\section{Date Day Activity}

1-28-97 (32) Pumping continuously since 1517 hrs on 1-27-97. IT collects grab samples. Remove some equipment from site. At $1515 \mathrm{hrs}$, total pumped $=62,684$ gallons.

1-29-97 (33) Continue pumping till $1215 \mathrm{hrs}$. IT collects grab samples. Total pumped during test $=116,346$ gallons. Backflushed discharge line and sampling equipment with $40 \mathrm{bbl}$ water tagged with $\mathrm{LiBr}$. Continue moving out equipment.

1-30-97 (34) Complete moving out equipment, leaving only IT sample van, transportainer, hose stands, and empty waste barrels (left per IT instruction). 
Table A-1-2

Well U-3cn PS\#2 Recompletion History

All work conducted on 10-hours-per-day, 4-days-per week basis.

See Table A-1-1 for activities at the BILBY site common to recompletion effort at both Hydrologic Test Hole U-3cn\#5 and Postshot Hole U-3en PS\#2.

Source: Bechtel Nevada NTS Daily Rig Operations Reports

Date

$12-18-96$

Operation shut down for holidays, 12-19-96 through 1-5-97.

$1-6-97$

$1-7-97$

$1-8-97$

$1-9-97$

1-14-97

$1-15-97$

$1-16-97$

$1-21-97$

$1-22-97$

Install electrical backboard. 1536 hrs. Drain hose back into well. gallons per minute. RadSafe monitors and analyzes.
Bring generator from U-7ba to site. Attempt to start same with no success.

Install pump control box to backboard; wire up generator to the control box. Lay out discharge hoses from sump to well.

Finish installing discharge hose, with "mini" lined sumps under each connection; drain valve and pressure gauge installed at the wellhead to drain the line after the pump test, if needed. Set up exclusion zone; lay plastic liner around wellihead. Start pump at 1513 hours (hrs); fluid to sump in 17 minutes. Shut off pump at

Wiring power to IT transportainer and working on automatic low-flow shut-off switch. IT rigs up flow meter. Repair IT generator.

IT continues rigging up. Lay auto-shut-off cable from sump to generator. Lay liner for extra fuel tank. Thaw discharge lines.

Wiring up low-flow switch. Try to thaw flow line; start pump in attempt to push ice out of line: no success. Continue trying to thaw line. Off-load and connect fuel tank. Start pump at $1440 \mathrm{hrs}$; fluid reaches sump in 19 minutes. Fluid allowed to run back through the pump. Restart pump at $1542 \mathrm{hrs}$; fluid to sump in 15 minutes. Pump test begins at 1600 hrs. Low-flow switch activated and set at 1.5

Pump test and sampling continue (since 1-16-97). IT takes samples and

IT takes samples. Pump shut off at 1330 hrs. Rig up and flush discharge hose and manifold with $\mathrm{LiBr}$-tagged water. Drain hoses and roll them up. RadSafe checks of connections show no contamination. 
Appendix A-2

Casing and Tubing Data for Hydrologic Test Hole U-3cn\#5 and Postshot Hole U-3cn PS\#2 
This Page Intentionally Left Blank. 
Table A-2-1

Casing and Tubing Data for Hydrologic Test Hole U-3cn\#5

\begin{tabular}{|c|c|c|c|c|c|c|c|}
\hline CASING & $\begin{array}{l}\text { Depth Interval } \\
\text { meters (feet) }\end{array}$ & Type & Grade & $\begin{array}{l}\text { Outside } \\
\text { Diameter } \\
\text { (inches) }\end{array}$ & $\begin{array}{c}\text { Inside } \\
\text { Diameter } \\
\text { centimeters } \\
\text { (inches) } \\
\end{array}$ & $\begin{array}{c}\text { Wall } \\
\text { Thickness } \\
\text { centimeters } \\
\text { (inches) } \\
\end{array}$ & $\begin{array}{l}\text { Weight } \\
\text { per Foot } \\
\text { pound/foot }\end{array}$ \\
\hline $\begin{array}{l}\text { Conductor } \\
\text { casing }\end{array}$ & $\begin{array}{l}0 \text { to } 11.0 \\
(0 \text { to } 36)\end{array}$ & $?$ & $?$ & 20 & $\begin{array}{l}49.53 \\
(19.5)\end{array}$ & $\begin{array}{l}0.635 \\
(0.25)\end{array}$ & 52.73 \\
\hline $\begin{array}{l}\text { Surface } \\
\text { casing }\end{array}$ & $\begin{array}{c}0 \text { to } 432.2 \\
(0 \text { to } 1,418)\end{array}$ & $\begin{array}{c}\text { Carbon } \\
\text { steel }\end{array}$ & J-55 & $133 \%$ & $\begin{array}{c}32.04 \\
(12.615)\end{array}$ & $\begin{array}{l}0.965 \\
(0.38)\end{array}$ & 54.5 \\
\hline $\begin{array}{l}\text { Intermediate } \\
\text { casing }\end{array}$ & $\begin{array}{c}0 \text { to } 726.9 \\
(0 \text { to } 2,385)\end{array}$ & $\begin{array}{c}\text { Carbon } \\
\text { steel }\end{array}$ & $J-55$ & $95 / 8$ & $\begin{array}{c}22.66 \\
(8.921)\end{array}$ & $\begin{array}{c}0.894 \\
(0.352)\end{array}$ & 36.0 \\
\hline Liner & $\begin{array}{c}707.4 \text { to } 863.2 \\
(2,321 \text { to } 2,832)\end{array}$ & $\begin{array}{c}\text { Carbon } \\
\text { steel }\end{array}$ & J-55 & $65 \%$ & $\begin{array}{c}15.04 \\
(5.921)\end{array}$ & $\begin{array}{c}0.894 \\
(0.352)\end{array}$ & 23.6 \\
\hline \multicolumn{8}{|l|}{ TUBING } \\
\hline Pump string & $\begin{array}{c}0 \text { to } 672.2 \\
(0 \text { to } 2,205.5)\end{array}$ & $\begin{array}{c}\text { Carbon } \\
\text { steel }\end{array}$ & $\mathrm{N}-80 ?$ & $27 / 8$ & $\begin{array}{c}6.20 \\
(2.441)\end{array}$ & $\begin{array}{c}0.551 \\
(0.217)\end{array}$ & 6.5 \\
\hline Access line & $\begin{array}{c}0 \text { to } 701.0 \\
(0 \text { to } 2,300)\end{array}$ & $\begin{array}{l}\text { Carbon } \\
\text { steel? }\end{array}$ & $?$ & $23 / 8$ & $?$ & $?$ & $?$ \\
\hline
\end{tabular}

Source: F\&S (1966a); BN (1997)

Note: Records cannot be found to verify data marked with "?".

Table A-2-2

Casing and Tubing Data for Postshot Hole U-3en PS\#2

\begin{tabular}{|c|c|c|c|c|c|c|c|}
\hline CASING & $\begin{array}{l}\text { Depth Interval } \\
\text { meters (feet) }\end{array}$ & Type & Grade & $\begin{array}{c}\text { Outside } \\
\text { Diameter } \\
\text { (inches) }\end{array}$ & $\begin{array}{c}\text { Inside } \\
\text { Diameter } \\
\text { centimeters } \\
\text { (inches) } \\
\end{array}$ & $\begin{array}{c}\text { Wall } \\
\text { Thickness } \\
\text { centimeters } \\
\text { (inches) } \\
\end{array}$ & $\begin{array}{c}\text { Weight } \\
\text { per Foot } \\
\text { pound/foot }\end{array}$ \\
\hline $\begin{array}{l}\text { Conductor } \\
\text { casing }\end{array}$ & $\begin{array}{l}0 \text { to } 24.4 \\
(0 \text { to } 80)\end{array}$ & $?^{a}$ & $?$ & 18 & $\begin{array}{c}43.8 \\
(17.25)\end{array}$ & $\begin{array}{c}0.953 \\
(0.375)\end{array}$ & 70.59 \\
\hline $\begin{array}{l}\text { Intermediate } \\
\text { casing }\end{array}$ & $\begin{array}{l}0 \text { to } 91.1 \\
(0 \text { to } 599)\end{array}$ & $\begin{array}{c}\text { Carbon } \\
\text { steel }\end{array}$ & $J-55$ & $103 / 4$ & $\begin{array}{c}25.5 \\
(10.05)\end{array}$ & $\begin{array}{l}0.889 \\
(0.35)\end{array}$ & 40.5 \\
\hline Pump casing & $\begin{array}{c}0 \text { to } 792.2 \\
(0 \text { to } 2,599)\end{array}$ & $?$ & $?$ & $4 \frac{1}{2}$ & $\begin{array}{l}10.16 \\
(4.0)\end{array}$ & $\begin{array}{l}0.635 \\
(0.25)\end{array}$ & $?$ \\
\hline \multicolumn{8}{|l|}{ TUBING } \\
\hline Pump string ${ }^{b}$ & $\begin{array}{c}0 \text { to } \sim 503 \\
(0 \text { to } \sim 1,650)\end{array}$ & Hydril $^{T M}$ & J-55 & $12 / 3$ & $?$ & $?$ & 2.4 \\
\hline
\end{tabular}

Source: F\&S (1966b); F\&S (1977); BN (1997)

a Records cannot be found to verify data marked with "?"

Pump string replaced in 1977. Record of exact tubing length not found, but top of pump intake noted at $503.5 \mathrm{~m}(1,652 \mathrm{ft})$. 
This Page Intentionally Left Blank. 
Appendix B

Stratigraphic and Lithologic Logs for Hydrologic Test Hole U-3cn\#5 
This Page Intentionally Left Blank. 
Stratigraphic Log of Hydrologic Test Hole U-3cn\#5

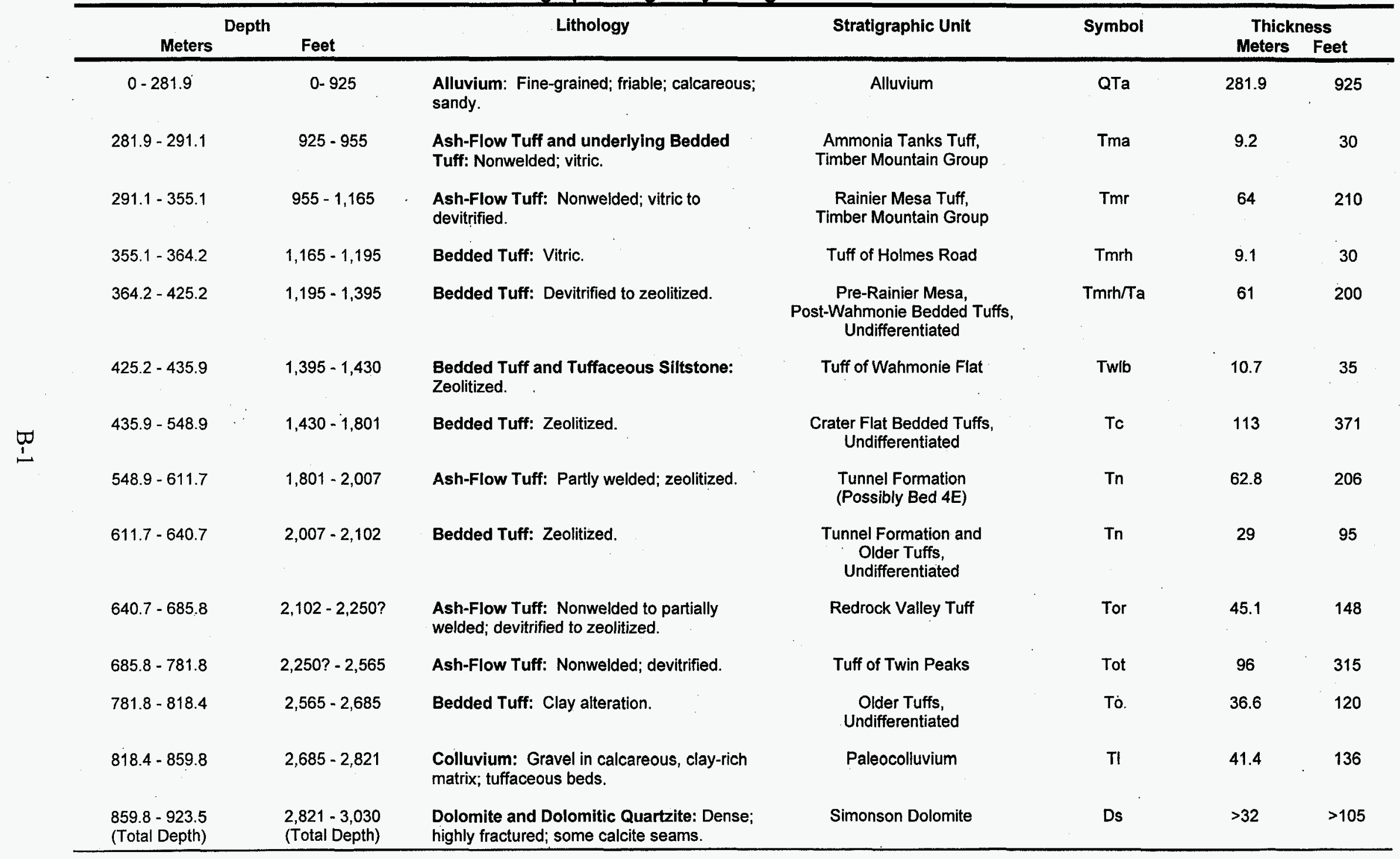

See U-3cn\#5 lithologic log.

Stratigraphic nomenclature from Ferguson and others (1994). 


\section{Lithologic Log of Hydrologic Test Hole U-3cn\#5 \\ (Logged by W.J. Carr, U.S. Geological Survey) \\ (Page 1 of 3 )}

Source: Dixon and others (1973). Stratigraphic nomenclature updated by Bechtel Geology, 1996.

\begin{tabular}{|c|c|c|}
\hline $\begin{array}{c}\text { Depth } \\
\text { Meters/(Feet) }\end{array}$ & Lithologic Description & $\begin{array}{l}\text { Stratigraphic } \\
\text { Unit }\end{array}$ \\
\hline $\begin{array}{l}0-281.9 \mathrm{~m} \\
(0-925 \mathrm{ft})\end{array}$ & $\begin{array}{l}\text { Alluvium: Fine-grained; friable; calcareous; sandy, } \\
\text { particularly lower part. }\end{array}$ & Alluvium \\
\hline $\begin{array}{l}281.9-288.0 \mathrm{~m} \\
(925-945 \mathrm{ft})\end{array}$ & $\begin{array}{l}\text { Nonwelded Ash-Flow Tuff: Very light-gray to yellowish- } \\
\text { gray; vitric; contains abundant quartz, feldspar, and biotite. }\end{array}$ & $\begin{array}{l}\text { Ammonia Tanks } \\
\text { Tuff, Timber } \\
\text { Mountain Group }\end{array}$ \\
\hline $\begin{array}{l}288.0-291.1 \mathrm{~m} \\
(945-955 \mathrm{ft})\end{array}$ & $\begin{array}{l}\text { Bedded Tuff: White; friable; fine-grained; contains } \\
\text { abundant shards. }\end{array}$ & \\
\hline $\begin{array}{l}291.1-304.8 \mathrm{~m} \\
(955-1,000 \mathrm{ft})\end{array}$ & $\begin{array}{l}\text { Nonwelded Ash-Flow Tuff: Gray to pinkish-gray; vitric; } \\
\text { shard-rich; contains quartz, feldspar, and biotite. }\end{array}$ & $\begin{array}{l}\text { Rainier Mesa } \\
\text { Tuff, Timber } \\
\text { Mountain Group }\end{array}$ \\
\hline $\begin{array}{l}304.8-312.4 m \\
(1,000-1,025 \mathrm{ft})\end{array}$ & $\begin{array}{l}\text { Nonwelded Ash-Flow Tuff: Light-brown, vitric, shard- } \\
\text { rich; contains a few small lithic fragments }\end{array}$ & $\begin{array}{l}\text { Rainier Mesa } \\
\text { Tuff, Timber } \\
\text { Mountain Group }\end{array}$ \\
\hline $\begin{array}{l}312.4-318.5 \mathrm{~m} \\
(1,025-1,045 \mathrm{ft})\end{array}$ & $\begin{array}{l}\text { Nonwelded Ash-Flow Tuff: Light-gray to pinkish-gray; } \\
\text { vitric }\end{array}$ & $\begin{array}{l}\text { Rainier Mesa } \\
\text { Tuff, Timber } \\
\text { Mountain Group }\end{array}$ \\
\hline $\begin{array}{l}318.5-330.7 \mathrm{~m} \\
(1,045-1,085 \mathrm{ft})\end{array}$ & $\begin{array}{l}\text { Nonwelded to Partly Welded Ash-Flow Tuff: Light-pink; } \\
\text { devitrified to vapor-phase crystallization; contains quartz, } \\
\text { feldspar, and biotite. }\end{array}$ & $\begin{array}{l}\text { Rainier Mesa } \\
\text { Tuff, Timber } \\
\text { Mountain Group }\end{array}$ \\
\hline $\begin{array}{c}330.7-355.1 \mathrm{~m} \\
(1,085-1,165 \mathrm{ft})\end{array}$ & $\begin{array}{l}\text { Nonwelded Ash-Flow Tuff: Light-pink, vitric; contains } \\
\text { common dark glass shards. }\end{array}$ & $\begin{array}{l}\text { Rainier Mesa } \\
\text { Tuff, Timber } \\
\text { Mountain Group }\end{array}$ \\
\hline $\begin{array}{l}355.1-364.2 \mathrm{~m} \\
(1,165-1,195 \mathrm{ft})\end{array}$ & $\begin{array}{l}\text { Bedded Tuff: Very light gray to light-tan; vitric; contains } \\
\text { abundant white pumice and abundant quartz, feldspar, } \\
\text { and biotite. May be bedded tuff or basal ash-flow of } \\
\text { Rainier Mesa Tuff. }\end{array}$ & $\begin{array}{l}\text { Tuff of Holmes } \\
\text { Road }\end{array}$ \\
\hline $\begin{array}{l}364.2-373.4 \mathrm{~m} \\
(1,195-1,225 \mathrm{ft})\end{array}$ & $\begin{array}{l}\text { Bedded Tuff: Light-gray; slightly zeolitized; contains small } \\
\text { dark lithic fragments, biotite, quartz, and feldspar. }\end{array}$ & $\begin{array}{l}\text { Pre-Rainier } \\
\text { Mesa, Post- } \\
\text { Wahmonie } \\
\text { Bedded Tuffs, } \\
\text { Undifferentiated }\end{array}$ \\
\hline $\begin{array}{l}373.4-388.6 \mathrm{~m} \\
(1,225-1,275 \mathrm{ft})\end{array}$ & $\begin{array}{l}\text { Bedded Tuff: Pinkish-tan; devitrified; fine-grained, crystal- } \\
\text { poor; contains small white pumice, and small lithic } \\
\text { fragments. }\end{array}$ & $\begin{array}{l}\text { Pre-Rainier } \\
\text { Mesa, Post- } \\
\text { Wahmonie } \\
\text { Bedded Tuffs, } \\
\text { Undifferentiated }\end{array}$ \\
\hline
\end{tabular}




\section{Lithologic Log of Hydrologic Test Hole U-3cn\#5 \\ (Logged by W.J. Carr, U.S. Geological Survey)}

(Page 2 of 3 )

\begin{tabular}{|c|c|c|}
\hline $\begin{array}{c}\text { Depth } \\
\text { Meters/(Feet) }\end{array}$ & Lithologic Description & $\begin{array}{l}\text { Stratigraphic } \\
\text { Unit }\end{array}$ \\
\hline $\begin{array}{l}388.6-390.1 \mathrm{~m} \\
(1,275-1,280 \mathrm{ft})\end{array}$ & $\begin{array}{l}\text { Bedded Tuff: Very light-gray; devitrified; contains } \\
\text { abundant large biotite flakes. }\end{array}$ & $\begin{array}{l}\text { Pre-Rainier } \\
\text { Mesa, Post- } \\
\text { Wahmonie } \\
\text { Bedded Tuffs, } \\
\text { Undifferentiated }\end{array}$ \\
\hline $\begin{array}{l}390.1-422.1 \mathrm{~m} \\
(1,280-1,385 \mathrm{ft})\end{array}$ & $\begin{array}{l}\text { Bedded Tuff: Tan to light-gray; zeolitized; friable; contains } \\
\text { rare biotite, feldspar, and quartz. }\end{array}$ & $\begin{array}{l}\text { Pre-Rainier } \\
\text { Mesa, Post- } \\
\text { Wahmonie } \\
\text { Bedded Tuffs, } \\
\text { Undifferentiated }\end{array}$ \\
\hline $\begin{array}{l}422.1-425.2 \mathrm{~m} \\
(1,385-1,395 \mathrm{ft})\end{array}$ & No cuttings available. & $\begin{array}{l}\text { Pre-Rainier } \\
\text { Mesa, Post- } \\
\text { Wahmonie } \\
\text { Bedded Tuffs, } \\
\text { Undifferentiated }\end{array}$ \\
\hline $\begin{array}{l}425.2-435.9 m \\
(1,395-1,430 \mathrm{ft})\end{array}$ & $\begin{array}{l}\text { Bedded Tuff and Tuffaceous Siltstone: Light-gray to } \\
\text { light-pink; zeolitized; contains abundant biotite, feldspar, } \\
\text { and altered light-green pyroxene. Dip of beds at } 433.4 \mathrm{~m} \\
(1,422 \mathrm{ft}) \text { is } 10^{\circ} \text {. }\end{array}$ & $\begin{array}{c}\text { Tuff of } \\
\text { Wahmonie Flat }\end{array}$ \\
\hline $\begin{array}{l}435.9-504.4 \mathrm{~m} \\
(1,430-1,655 \mathrm{ft})\end{array}$ & $\begin{array}{l}\text { Bedded Tuff: Yellow to light-brown; zeolitized; fine- } \\
\text { grained; contains some biotite, quart, feldspar, and small } \\
\text { lithic fragments. }\end{array}$ & $\begin{array}{l}\text { Crater Flat } \\
\text { Bedded Tuffs, } \\
\text { Undifferentiated }\end{array}$ \\
\hline $\begin{array}{l}504.4-548.9 \mathrm{~m} \\
(1,655-1,801 \mathrm{ft})\end{array}$ & $\begin{array}{l}\text { Bedded Tuff: Pink, light-gray to yellowish-gray and white; } \\
\text { zeolitized; contains rare to common crystals of quartz, } \\
\text { feldspar, and biotite; small } 0.6-0.3 \mathrm{~cm}(1 / 4-1 / 8 \mathrm{in} \text {.) Dark } \\
\text { volcanic lithic fragments are common. Zone } 546.8-548.9 \\
\mathrm{~m}(1,794 \text { to } 1,801 \mathrm{ft}) \text { contains much broken rock and clay, } \\
\text { it is stained red and yellow and may be a fault zone or } \\
\text { possibly a clay enrichment zone at top of the underlying } \\
\text { ash-flow tuff. Thin section taken from } 541.6 \mathrm{~m}(1,777 \mathrm{ft}) \text {. }\end{array}$ & $\begin{array}{l}\text { Crater Flat } \\
\text { Bedded Tuffs, } \\
\text { Undifferentiated }\end{array}$ \\
\hline $\begin{array}{l}548.9-611.7 m \\
(1,801-2,007 \mathrm{ft})\end{array}$ & $\begin{array}{l}\text { Partly Welded Ash-Flow Tuff: Light-gray to yellowish- } \\
\text { gray; contains } 10 \text { percent phenocrysts of quartz, feldspar, } \\
\text { and hornblende, and } 5-10 \text { percent gray and purple lithic } \\
\text { fragments } 0.2-1.3 \mathrm{~cm}(1 / 16-1 / 2 \text { in.) In diameter. } \\
\text { Pumice is pink and yellow. Thin sections taken from } 568.5 \\
\mathrm{~m}(1,865 \mathrm{ft}), 576.7 \mathrm{~m}(1,892 \mathrm{ft}) \text {, and } 586.4 \mathrm{~m}(1,924 \mathrm{ft}) \text {. }\end{array}$ & $\begin{array}{l}\text { Tunnel } \\
\text { Formation } \\
\text { (Possibly Bed } \\
\text { 4E) }\end{array}$ \\
\hline $\begin{array}{l}611.7-640.7 \mathrm{~m} \\
(2,007-2,102 \mathrm{ft})\end{array}$ & $\begin{array}{l}\text { Bedded Tuff: Red, light-tan and light orange-brown, fine- } \\
\text { to medium-grained; most beds contain common biotite, } \\
\text { quartz, and feldspar; rare to common dark volcanic and } \\
\text { locally Paleozoic lithic fragments. Dip of bedding at }\end{array}$ & $\begin{array}{l}\text { Tunnel } \\
\text { Formation and } \\
\text { Older Tuffs, } \\
\text { Undifferentiated }\end{array}$ \\
\hline
\end{tabular}




\section{Lithologic Log of Hydrologic Test Hole U-3cn \#5 (Logged by W.J. Carr, U.S. Geological Survey) (Page 3 of 3 )}

\begin{tabular}{|c|c|c|}
\hline $\begin{array}{c}\text { Depth } \\
\text { Meters/(Feet) }\end{array}$ & Lithologic Description & $\begin{array}{c}\text { Stratigraphic } \\
\text { Unit }\end{array}$ \\
\hline $\begin{array}{c}640.7-685.8 \mathrm{~m} \\
(2,102-2,250 ? \mathrm{ft})\end{array}$ & $\begin{array}{l}\text { Nonwelded to Moderately Welded Ash-Flow Tuff: } \\
\text { Light-gray to pink, devitrified to zeolitized; contains } \\
5-10 \text { percent phenocrysts of quartz, feldspar, and biotite; } \\
\text { also contains rare dark purple porphyritic lithic fragments } \\
\text { as large as } 2.5 \mathrm{~cm} \text { ( } 1 \text { in.). Thin sections taken from } \\
641.9 \mathrm{~m}(2,106 \mathrm{ft}) \text { and } 664.5 \mathrm{~m}(2,180 \mathrm{ft}) \text {. }\end{array}$ & $\begin{array}{l}\text { Redrock Valley } \\
\text { Tuff. }\end{array}$ \\
\hline $\begin{array}{c}685.8-781.8 m \\
(2,250 ?-2,565 f t)\end{array}$ & $\begin{array}{l}\text { Nonwelded Ash-Flow Tuff: Light-gray; devitrified; } \\
\text { contains common feldspar and biotite with rare quartz; } \\
\text { phenocrysts more common at } 757.4-765.0(?) \mathrm{m} \\
(2,485-2,510 \mathrm{ft}) \text {. Locally contains abundant lithic } \\
\text { fragments. Possible fault zone near or at top of unit } \\
691.9(?)-698.0(?) \mathrm{m}(2,270[?]-2,290[?] \mathrm{ft}) \text { may be } \\
\text { contact between Redrock Vailey Tuff and Tuff of Twin } \\
\text { Peaks. Thin sections taken from } 688.8 \mathrm{~m}(2,260 \mathrm{ft}) \text {, } \\
701.0 \mathrm{~m}(2,300 \mathrm{ft}) \text {; and } 730.0 \mathrm{~m}(2,395 \mathrm{ft}) \text {. }\end{array}$ & $\begin{array}{l}\text { Tuff of Twin } \\
\text { Peaks }\end{array}$ \\
\hline $\begin{array}{c}781.8-818.4 m \\
(2,565-2,685 \mathrm{ft})\end{array}$ & $\begin{array}{l}\text { Bedded Tuff with Clayey Alteration: Light-gray to } \\
\text { reddish-brown; Clayey alteration contains rare to common } \\
\text { feldspar, quartz, and biotite. }\end{array}$ & $\begin{array}{l}\text { Older Tuffs, } \\
\text { Undifferentiated }\end{array}$ \\
\hline $\begin{array}{c}818.4-859.8 \mathrm{~m} \\
(2,685-2,821 \mathrm{ft})\end{array}$ & $\begin{array}{l}\text { Colluvium: Very light-gray to reddish-brown; rich in clay; } \\
\text { tuffaceous fragments and Paleozoic rock fragments. } \\
\text { Rock consists largely of a colluvial gravel in weakly } \\
\text { cemented calcareous and clayey matrix. Fragments are } \\
\text { gray dolomite and limestone, and light-gray quartzite; } \\
\text { unsorted. Fragments are subangular to subrounded } \\
1.3-7.6 \mathrm{~cm}(1 / 2-3 \mathrm{in} \text {.) In diameter. Interval contains rare } \\
15.2-25.4 \mathrm{~cm}(6-10 \mathrm{in} \text {.) Thick beds of pink to tan clayey } \\
\text { tuffaceous sandstone. Core at } 835.2-840.9 \mathrm{~m} \\
(2,740-2,759 \mathrm{ft}) \text { contains somewhat more rounded gray } \\
\text { to olive-green fragments of slightly calcareous, poorly } \\
\text { indurated clayey sandstone. Common black } \\
\text { carbonaceous plant remains. }\end{array}$ & Paleocolluvium \\
\hline $\begin{array}{c}859.8-891.5 \mathrm{~m} \\
(2,821-2,925 \mathrm{ft})\end{array}$ & $\begin{array}{l}\text { Dolomite: Light and medium gray to light brownish-gray; } \\
\text { fine- to medium-grained; dense; locally contains seams of } \\
\text { calcite. Fractures present at } 863.5 \mathrm{~m}(2,833 \mathrm{ft}), 864.4 \mathrm{~m} \\
(2,836 \mathrm{ft}), 866.2(2,842 \mathrm{ft}) ; \text { rock is highly fractured } \\
\text { between } 868.7 \text { and } 876.3 \mathrm{~m}(2,850 \text { and } 2,875 \mathrm{ft}) \text {. }\end{array}$ & $\begin{array}{l}\text { Paleozoic } \\
\text { Rocks, } \\
\text { Simonson } \\
\text { Dolomite? }\end{array}$ \\
\hline $\begin{array}{c}891.5-923.5 \mathrm{~m} \\
(2,925-3,030 \mathrm{ft}) \\
(\text { Total Depth) }\end{array}$ & $\begin{array}{l}\text { Dolomitic Quartzite: Light tan; fairly well sorted, contains } \\
50 \text { percent subrounded quartz grains; locally contains } \\
\text { reddish-brown stains; fairly well indurated. Thin sections } \\
\text { taken from } 892.5 \text { and } 923.5 \mathrm{~m}(2,928 \text { and } 3,030 \mathrm{ft}) \text {. Small } \\
\text { fault at top of interval. }\end{array}$ & \\
\hline
\end{tabular}




\section{Distribution List}

Copies

Copies

R.M. Bangerter

2 D. Trudeau

Environmental Restoration Division

DOE/Nevada Operations Office

P.O. Box 98518, MS 505

U.S. Geological Survey

Water Resources Division

6770 South Paradise Road

Las Vegas, NV 89193-8518

Las Vegas, NV 89119

D.W. Duncan

Environmental Restoration Division

DOE/Nevada Operations Office

P.O. Box 98518, MS 505

Las Vegas, NV 89193-8518

DOE Nevada Operations Office

Technical Information Resource Center

P. O. Box 98518

Las Vegas, NV 89193-8518

Janet Wille

IT Corporation

P.O. Box 93838, MS 439

Las Vegas, NV 89193-3838

W.L. Hawkins

C.E. Russell

Desert Research Institute

755 East Flamingo Road

P.O. Box 19040

Las Vegas, NV 89132

1 D.K. Smith

1

Lawrence Livermore National Laboratory

P.O. Box 808

Livermore, CA 94550

$1 \quad$ U.S. Department of Energy

2

Office of Scientific and Technical Information 175 Oak Ridge Turnpike

P.O. Box 62

Oak Ridge, TN 37831

Los Alamos National Laboratory

P.O. Box 1663

Los Alamos, NM 87545

IT Library

P.O. Box 93838, MS 439

Las Vegas, NV 89193-3838

P.K. Ortego

Bechtel Nevada

P.O. Box 98521 , MS NLV082

Las Vegas, NV 89193-8521

G.A. Pawloski

Lawrence Livermore National Laboratory

P.O. Box 808

Livermore, CA 94550 
This Page Intentionally Left Blank. 